\title{
Patent pools and clearinghouses in the life sciences: back to the future
}

\section{Geertrui Van Overwalle}

Paper submitted in February 2016 for publication in: Research Handbook on IP and the Life Sciences, D. Matthews \& H. Zech (eds.), Edward Elgar, 2016

\section{Introduction}

Patents in the life sciences sector have sparked considerable debate over the past years. The grant of a series of patents for the screening of breast cancer (BRCA) genes led to wide controversy in Europe, the US and Australia. ${ }^{1}$ The grant of patents for plants resulting from essentially biological processes, notably tomatoes with reduced fruit water content and broccoli with anti-cancer potential, also spurred stormy disputes. ${ }^{2}$ Decisions on the scope of plant biotech patents equally fueled a legal battle. ${ }^{3}$ Last but not least, the grant of patents for human embryonic stem cells in the US, triggered fierce discussions in Europe. $^{4}$

In the ongoing debate, concern has been expressed about the potential hindering effect on innovation of the continuous increase of patents in the life sciences. The academic debate on the possible discouraging impact of the proliferation of patents was set in motion by the seminal article from Heller and Eisenberg 'Can Patents Deter Innovation? The Anticommons in Biomedical Research' in 1998. ${ }^{5}$ Over the years, various strategies have been

\footnotetext{
The author is very grateful to Amandine Léonard for her valuable research assistance.

${ }^{1}$ For details, see chapters 1.4 (Waechter), 1.5 (Minssen), 1.6 (Gosh) and 1.7 (Rimmer) in the present book. Also see G. Matthijs, I. Huys, G. Van Overwalle \& D. Stoppa-Lyonnet, 'The European BRCA Patent Oppositions and Appeals: Coloring inside the Lines' [2013] 31 Nature Biotechnology, 704-710; I. Huys, G. Matthijs \& G. Van Overwalle, 'The Fate and Future of Patents on Human Genes and Genetic Diagnostic Methods' [2012] 13 (6) Nature Reviews Genetics, 441-448; Van Overwalle, G. 'Gene Patents and Human Rights', in Intellectual Property and Human Rights [2015] Paul L. C. Torremans (ed.), Kluwer Law International, 871-914.

${ }^{2}$ For details, see chapters 2.1 (Würtenberger), 2.2 (Kock), 2.3 (Janis) and 2.4 (Allred) in the present book. Also see, Van Overwalle, G., 'Smart Innovation and Inclusive Patents for Sustainable Food and Health Care: Redefining the Europe 2020 Objectives', in Constructing European Intellectual Property. Achievements and New Perspectives, Geiger, C. (ed.), Edward Elgar, 2013, 231-254.

${ }^{3}$ For details, see chapter 2.6 (Metzger) in the present book. Also see, Van Overwalle, G. 'The CJEU Monsanto Soybean Decision and Patent Scope: As Clear As Mud', International Review of Intellectual Property and Competition Law (IIC), 2011, 1-3.

${ }^{4}$ For details, see chapters 3.1 (Plomer) and 3.2. (Golden) in the present book. Also see Hellstadius, A., A Quest for Clarity. Reconstructing Standards for the Patent Law Morality Exclusion (PhD Stockholm University), Stockholm, April 2015.

5 M. A. Heller \& R. S. Eisenberg, 'Can Patents Deter Innovation? The Anticommons in Biomedical Research' [1998] 280 Science 698.
} 
suggested in scholarly literature to mitigate the alleged hindering effect. ${ }^{6}$ A first suggestion was to narrow down patentable subject matter, notably to carve out human genes from patent protection. This approach was applied in the recent verdicts of the US Supreme Court ${ }^{7}$ and the Australian High Court. ${ }^{8}$ In the slipstream of those verdicts, the patentability of human genes might be challenged before the Court of Justice of the EU, based on the argument that isolated human genes do not meet the definition of 'invention'. A second approach was to strengthen patentability requirements. The "raise the bar" approach to grant "high quality patents" is still pursued today. ${ }^{9}$ A third approach was to limit the scope of patents, and insert purpose bound protection. ${ }^{10} \mathrm{~A}$ fourth response was to broaden exemption regimes in patent law, more in particular widen the research exemption. ${ }^{11}$ In the same vein, the introduction of a so-called breeder's exemption is contemplated at present. ${ }^{12}$

Our past research aimed at contributing to the anti-commons debate in two ways. A first objective was to assess whether the prevailing assumption that an anti-commons problem was present in biomedical sciences held out in the field of human genetics. Despite the level of academic interest, the anti-commons theory remained largely untested at the time. Initial empirical research carried out at by Jensen and Murray, mainly applying a quantitative approach, seemed to confirm the anti-commons hypothesis. ${ }^{13}$ In contrast, our research, applying a more qualitative assessment of gene patent claims, did not confirm

\footnotetext{
${ }^{6}$ For a concise review, see G. Van Overwalle, 'Turning Patent Swords into Shares', 330 Science, [2010] (issue 6011), 1630-1631 and the references cited there.

${ }^{7}$ US Supreme Court, June 132013 (Association for Molecular Pathology et al. v. Myriad Genetics Inc. et al.) (available at http://www.supremecourt.gov/opinions/12pdf/12-398 1b7d.pdf, last visited October 27 2015).The Supreme Court held that a naturally occurring DNA segment is a product of nature and not patent eligible merely because it has been isolated, but cDNA is patent eligible because it is not naturally occurring.

${ }^{8}$ High Court of Australia, October 72015 (D'arcy V Myriad Genetics Inc \& Anor), HCA 35 (available at http://www.hcourt.gov.au/assets/publications/judgment-summaries/2015/hca-35-2015-10-07.pdf, last visited October 12, 2015). The High Court held that an isolated nucleic acid, coding for a BRCA1 protein, with specific variations from the norm that are indicative of susceptibility to breast cancer and ovarian cancer (BRCA), was not a "patentable invention" within the meaning of s 18(1)(a) of the Patents Act 1990. For an in-depth analysis, see L. Palombo, EIPR (forthcoming).

${ }^{9}$ Cf. EPO Economic and Scientific Advisory Board, Report on Patent Quality, European Patent Office, May 7 2012, Munich (available at http://www.epo.org/about-us/office/esab/workshops.html, last visited October 14, 2015). On the notion of 'high quality patents' the interested reader might care to consult G. Van Overwalle, 'The Impact of Emerging Market Patent Systems on Europe: Awaiting 'The Rape Of Europa'?, in Emerging Markets and the World Patent Order, F. M. Abbott, C. M. Correa \& P. Drahos (eds.), Edward Elgar, 2013, 355-368.

${ }^{10}$ For a comprehensive review on this topic, see J. Lai, 'Gene-related inventions in Europe: purpose- vs function-bound protection' [2015] 11 Queen Mary Journal of Intellectual Property, 449-473.

${ }^{11}$ For an interesting review on this topic, see E. Van Zimmeren, \& G. Van Overwalle, 'A False Sense of Security Offered by Zero-Price Liability Rules? Research Exceptions in the United States, Europe and Japan in an Open Innovation Context', in Patent Law in Global Perspective, R. L. Okediji \& M. A. Bagley, (eds.), Oxford, Oxford University Press [2014] 379-417.

${ }_{12}$ Cf. article 27 (3) Agreement on a Unified Patent Court, Brussels, 11 January 2013 (available at http://register.consilium.europa.eu, last visited November 17, 2015).

${ }^{13}$ K. Jensen \& F. Murray, 'Intellectual Property Landscape of the Human Genome' [2005] 310 Science, 239-240. Cf. M. M Hopkins, S. Mahdi, P. Patel \& S. Thomas, 'DNA Patenting: The End of an Era?' [2007] 25 Nature Biotechnology, 185-187.
} 
the emergence of a wide patent thicket in human genetics. ${ }^{14}$ However, our empirical study found that there was some reason for concern in the field of diagnostic testing, in view of the upsurge of whole genome sequencing.

A second objective or our research was to explore solutions to the acclaimed anticommons problem in the field of genetics. Rather than focusing on legislative (public ordering) measures, we explored to what extent collaborative licensing mechanisms (private ordering measures), such as patent pools and clearinghouses, could act as useful mechanisms to remedy possible adverse effects of fragmentation in the area of genetics. ${ }^{15}$ Our research found that the major challenge to implement collaborative rights institutions in the genetic field was not so much conceptual in nature - implying that such models could be moulded into a genetic context - but rather related to the economic viability of those models in a genetic milieu. Tuned down by a sense of realism, we concluded that the best option was either to concentrate on patent pools set up around a limited technological field, or on well focused patent standard clearinghouses. ${ }^{16}$

The present chapter aims at re-visiting our former insights in a present-day context. First, we want to re-examine the patent proliferation phenomenon and related anti-commons problem by investigating the patent growth and re-assessing the existence of patent thickets in the life sciences (Section 2). Second, and most importantly, we wish to re-visit the collaborative license solution, by taking stock of new models and trends (Section 3), and by carrying out an in-depth analysis of operative models (Section 4). We close by summarizing lessons learned from the past, which might be meaningful for (re-)writing the future (Section 5).

\footnotetext{
${ }^{14}$ See I. Huys, N. Berthels, G. Matthijs \& G. Van Overwalle, 'Legal Uncertainty in the Area of Genetic Diagnostic Testing' [2009] 27 Nature Biotechnology, 903-909. Also see E. van Zimmeren, Towards a New Patent Paradigm in the Biomedical Sector? Facilitating Access, Open Innovation and Social Responsibility in Patent Law in the US, Europe and Japan, PhD, Leuven University [2011], 16 May 2011, 110-126 (on file with the author - hard copy available in the library of the Faculty of Law, Leuven University, Tiensestraat 41, 3000 Leuven, Belgium - see http://bib.kuleuven.be/rbib/).

${ }^{15}$ See G. Van Overwalle, 'Designing Models to Clear Patent Thickets in Genetics', in Working within the Boundaries of Intellectual Property, R. Dreyfuss, H. First D. and Zimmerman (eds.), Oxford, OUP, 2010, 305-324 (further abbreviated as G. Van Overwalle [2010]); G. Van Overwalle (ed.), Gene Patents and Collaborative Licensing Models. Patent Pools, Clearinghouses, Open Source Models and Liability Regimes, Cambridge, CUP, 2009; G. Van Overwalle, 'Of Thickets, Blocks and Gaps: Designing Tools to Resolve Obstacles in the Gene Patents Landscape', in Gene Patents and Collaborative Licensing Models, Van Overwalle, G. (ed.), Cambridge, Cambridge University Press, 2009, 381-463 (further abbreviated as G. Van Overwalle [2009]); G. Van Overwalle et al., 'Models for Facilitating Access to Patents on Genetic Inventions', 7 Nature Review Genetics, 2006, 143 ff. Also see E. van Zimmeren, S. Vanneste, G. Matthijs, W. Vanhaverbeke \& G. Van Overwalle, 'Patent Pools and Clearinghouses in the Life Sciences' [2011] 29 (11) Trends in Biotechnology, 569-576; E. van Zimmeren, 'Clearinghouse Mechanisms in Genetic Diagnostics: Conceptual Framework', in Gene Patents and Collaborative Licensing Models, G. Van Overwalle (ed.), Cambridge, CUP, 2009, 63-119; E. van Zimmeren, B. Verbeure, G. Matthijs \& G. Van Overwalle, 'A Clearinghouse for Diagnostic Testing: the Solution to Ensure Access to and Use of Patented Genetic Inventions?', Bulletin of the World Health Organization, 2006, 352-359; Verbeure, B., 'Patent Pooling for Gene-Based Diagnostic Testing: Conceptual Framework', in Gene Patents and Collaborative Licensing Models, G. Van Overwalle (ed.), Cambridge, CUP, 2009, 3-32; B. Verbeure, E. van Zimmeren, G. Matthijs \& G. Van Overwalle, 'Patent Pools and Diagnostic Testing', 24 Trends in Biotechnology, 2006, 115 .

${ }^{16}$ See G. Van Overwalle [2009] footnote 15.
} 


\section{Patent growth and patent thickets}

\subsection{Increase of patents}

One of the most striking aspects of the intellectual property (IP) system in recent years is the ongoing worldwide increase of intellectual property rights (IPRs) in general, ${ }^{17}$ and of patents and patent applications in particular. ${ }^{18}$ At first sight, life sciences is a field with a very high volume of patents and patent applications. On closer inspection, a more nuanced picture arises: in Europe biotechnology grew the fastest in 2014, taking the 8th place in the top ten of technical fields, ${ }^{19}$ while applications in pharmaceuticals dropped significantly for the second year in a row, but still taking the 10th place in the top ten of technical fields. ${ }^{20}$

The overall growth of patents has been attributed to several factors. First and foremost, the increase of patents has been said to be caused by technological complexity. ${ }^{21}$ Complex technology sectors are characterized by the need to assemble multiple elements to develop a final product. ${ }^{22}$ These sectors are therefore more sensitive to this trend. ${ }^{23} \mathrm{~A}$ second cause is the growing importance of sequential technologies. Innovation across the economy is becoming more cumulative in nature, building on previous inventions and innovations. ${ }^{24} \mathrm{~A}$ third factor is the explosive growth in innovation in sectors like the ICT

\footnotetext{
${ }^{17}$ As to IP applications, 2.35 million patent applications are estimated to have been filed worldwide in 2012 , representing an increase of $9.2 \%$ on 2011 , which is the highest rate recorded in 18 years; utility model applications total 827,500 , representing a growth of $23.4 \%$ on the previous year's figures; the number of classes specified in trademark applications saw growth of $6 \%$, reaching 6.58 million; lastly, the 1.22 million industrial designs contained in applications grew by $17 \%$, the highest growth on record (See WIPO IP Facts and Figures, WIPO, 2013, p. 4 (available at http://www.wipo.int/edocs/pubdocs/en/statistics/943/wipo pub 943 2013.pdf, last visited October 19, 2015). As to IP rights in force, at 82 offices around the world 8.66 million patents were in force, representing $7.9 \%$ more than in 2011 ; a total of 1.87 million utility models were in force at the 45 offices that maintain these statistics; approximately 24 million trademark registrations were active at 74 offices worldwide; lastly, about 2.71 million industrial design registrations were in force at 76 offices (Ibidem, p. 10). For more details and context, see Emerging Markets and the World Patent Order, F. M. Abbott, C.M. Correa \& P. Drahos (eds.), Edward Elgar, 2013.

${ }_{18}$ As to European patent applications at the EPO their figure grew by $2.7 \%$ in 2014 to a record high of 151.981 (see EPO Annual Report 2014, available at http://www.epo.org/about-us/annual-reportsstatistics/annual-report/2014/statistics.html, last visited October 26, 2015).

${ }_{19}$ With 5.905 applications in 2014 and an increase of 12,1\% compared to 2013 (see EPO Annual Report 2014, available at http://www.epo.org/about-us/annual-reports-statistics/annual-report/2014/statistics.html, last visited October 26, 2015).

20 With still 5.270 applications in 2014 (see EPO Annual Report 2014, available at http://www.epo.org/about-us/annual-reports-statistics/annual-report/2014/statistics.html, last visited October 26, 2015.

${ }^{21}$ B. H. Hall, 'Exploring the Patent Explosion' [2004] The Journal of Technology Transfer, 35-48.

${ }^{22}$ R. C. Levin, A.K. Klevorick, R.R. Nelson \& S.G. Winter, 'Appropriating the Returns from Industrial Research and Development' [1987] 3 Brookings Papers on Economic Activity, 783. Also see D.L. Burk \& M.A. Lemley, The Patent Crisis and How the Courts Can Solve It, Chicago-London, The University of Chicago Press [2009].

${ }^{23}$ S. Woolman, E. Fishman \& M. Fisher, 'Evidence of patent thickets in complex biopharmaceutical technologies' [2013] Idea - Journal of Law and Technology, 1-38.

${ }^{24}$ I. Hargreaves, Digital Opportunity. A Review of Intellectual Property and Growth. An independent report (Study commissioned by the UK Prime Minister in November 2010), 2011 (available at
} 
and biotechnology industry. Dissenting voices suggest, however, that the rise of patents does not correspond to a dramatic increase in the overall levels of innovation at all. ${ }^{25} \mathrm{~A}$ fourth factor is said to be uncertainty in the legal system. Uncertainty in the patent system has a counter-intuitive effect: instead of using it less, firms are choosing to file for more patents, either to fend off perceived threats or to take advantage of the weakness in the system. ${ }^{26}$

\subsection{Patent thickets. Concept}

The burning question following from the brief statistical overview is, whether the increasing use of patent leads to patent thickets in the life sciences. Before embarking on this issue, let us first (re-)address the notion of IP thickets in general, and patent thickets in particular.

With the ICT sector in mind, Merges cautioned for a possible IP thicket, defining such an IP thicket as "a tangled, twisted mass of intellectual property rights, which criss-cross the established walkways of commerce" and where progress requires "numerous contracts with multiple, independent right holders" ${ }^{27}$ In the same sense, Shapiro spoke of "a dense web of overlapping intellectual property rights that a company must hack its way through in order to actually commercialize new technology". ${ }^{28}$ Ullrich resonated this approach where he argued that a patent thicket may be present when "the field is crowded by a large number of patents, with ownership being dispersed among many patentees, so that it becomes impossible for anyone to work naturally coherent pieces of the technology without first obtaining consent by many other patentees". ${ }^{29}$ Carefully reading the various definitions suggests that a patent thicket is likely to emerge when a multitude of IP rights is held by multiple IP owners. ${ }^{30}$

https://www.gov.uk/government/uploads/system/uploads/attachment_data/file/32563/ipreview-

finalreport.pdf, last visited October 19, 2015).

${ }^{25}$ J.E. Bessen \& M.J. Meurer, Patent failure: How judges, bureaucrats, and lawyers put innovators at risk, Princeton University Press [2008].

${ }^{26}$ Hargreaves [2011] footnote 24.

${ }^{27}$ R. P. Merges, 'Contracting Into Liability Rules: Intellectual Property Rights and Collective Rights Organizations' [1996] 84 Calif. Law Rev. 1293-1393. Merges already introduced the "thickets" metaphor in this article: "Intellectual property experts, especially scholars, have responded to this burgeoning thicket of rights..." (p. 1386) and "This Article is aimed at providing conceptual guidance for those who need to traverse the new thicket of intellectual property rights. Each vine, each plant, standing in one's path represents a distinct IPR owned by an individual. To pass through, one needs a license from each owner. Where a single right blocks the path, this is easy: a single licensing contract does the trick. Today, however, business people more often than not encounter a tangled, twisted mass of IPRs, which criss-cross the established walkways of commerce. Progress along this path does not come cheaply: rather, it requires numerous contracts with multiple, independent right holders." (p. 1295).

${ }^{28}$ C. Shapiro, 'Navigating the Patent Thicket: Cross Licenses, Patent Pools and Standard Setting' in Innovation Policy and the Economy (Vol. I), E. Jaffe et al. (eds.), MIT Press, 2001, 119-150.

${ }^{29} \mathrm{H}$. Ullrich, 'Gene Patents and Clearing Models. Some Comments from a Competition Law Perspective', Gene Patents and Collaborative Licensing Models, Geertrui Van Overwalle (ed.), Cambridge, CUP, 2009, 339-350.

${ }^{30}$ Cf. EPO Economic and Scientific Advisory Board, Report on Patent Thickets, Leuven, 26 September 2012 (available at http://www.epo.org/about-us/office/esab/workshops.html, last visited October 21, 2015). 
These definitions are unsatisfactory, for two reasons. First, the definitions do not clarify whether an IP thicket is present when the IP rights are numerous, or whether an IP thicket appears when the many IP rights at stake are also essential. More recently, some observers have indicated that a patent thicket is really present if there is a "critical mass of essential patent holders with a critical mass of essential patents". ${ }^{31}$ In line with previous writings, we take the view that a patent thicket refers to a multitude of essential, patents which are held by a multitude of patent owners. ${ }^{32}$

Second, the definitions mix up the problem of fragmentation and overlap. The problem of fragmentation of essential patents revolves around "divided entitlements among complements"33 (see Figure 1), which can occur either horizontally or vertically. Horizontal fragmentation occurs if patents cover different pieces that must be integrated into a product and vertical fragmentation takes place if patents cover different steps in a cumulative innovation process. ${ }^{34}$ Scholars point to the risk of bargaining breakdown whenever the development of a product requires permission from the owners of two or more inputs. ${ }^{35}$ In contrast, the problem of overlap points to a closely related albeit different problem. Multiple patents often cover the same ground, as different parties may be able to lay claim to the same subject matter technologies or to aspects of the same technology. ${ }^{36}$ (see Figure 1). Like the fragmentation problem, the overlap problem has the potential to prevent all parties from making a final product that incorporates multiple inventions. But where the fragmentation problem focuses on the need to aggregate dispersed property rights and the difficulty of assembling those fragments into a coherent product, the overlap problem suggests that patents should be phrased narrower than they are, so that the problem of overlapping scope will not arise. However, even with such narrower, non-overlapping patents, a fragmentation problem may persist. So, both fragmentation and overlap may inhibit a swift assembly of patents and give rise to an anti-commons problem.

\footnotetext{
31 L. A. Horn, 'The MPEG LA ${ }^{\circledR}$ Licensing Model. What Problem Does It Solve in Biopharma and Genetics', in Gene Patents and Collaborative Licensing Models, G. Van Overwalle (ed.), Cambridge, CUP, 2009, 33-41. In the same sense, J.A. Goldstein, 'Critical Analysis of Patent Pools', in Gene Patents and Collaborative Licensing Models, G. Van Overwalle (ed.), Cambridge, CUP, 2009, 50-60.

${ }^{32}$ In the same sense, G. von Graevenitz, S. Wagner \& D. Harhoff, 'How to measure patent thickets - A novel approach', 111 Economics Letters, Issue 1, April 2011, 6-9, characterizing a patent thicket as involving (1) multiple patents or patent applications on (2) the same, similar, or complementary technologies, (3) held by different parties.

${ }^{33}$ D.L. Burk \& M.A. Lemley, 'Policy Levers in Patent Law', Minnesota Public Law Research Paper No. 03-11 and UC Berkeley Public Law Research Paper No. 135 (available at http://ssrn.com/abstract=431360, last visited October 21, 2015). A similar - correct - distinction between fragmentation and overlap can be found at D. Krauspenhaar, Liability Rules in Patent Law. A Legal and Economic Analysis, BerlinHeidelberg, Springer [2015] 53 ff.

${ }^{34}$ Burk \& Lemley, footnote 33.

${ }^{35}$ Burk \& Lemley, footnote 33.

${ }^{36}$ Burk \& Lemley, footnote 33. Also see Bessen, \& Meurer, 2008, footnote 25.
} 


\section{Fragmentation}

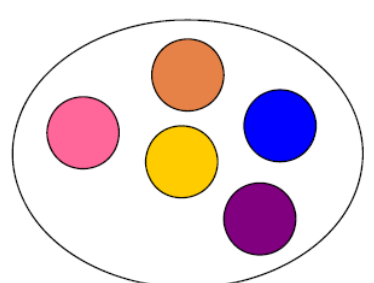

Overlap

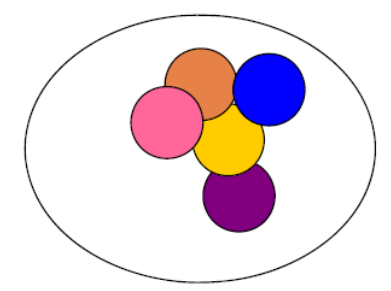

Figure 1. Distinction between patent fragmentation (patent thicket) and patent overlap

\subsection{Patent thickets in the life sciences?}

Within the life sciences sector, the debate on patent thickets kicked off in the sector of human biotechnology with the paper from Heller and Eisenberg. ${ }^{37}$ Our initial empirical research, assessing the potentially blocking effect of gene patents in Europe and in the US, provided a basis to tune down the alarming tone of the debate in genetics. ${ }^{38}$ More recent empirical research confirms our findings. First, a survey, interrogating technology players in the medical biotechnology field in Europe and Australia, does not provide further evidence of the existence of a vast patent thicket in medical biotechnology. ${ }^{39}$ Only $25 \%$ of the respondents in the sample perceived the encountered number of third party patent rights as a substantial obstacle in their organisation's path to research, product development and/or the provision of (clinical testing) services. Therefore, it is not possible to conclude from this data that a patent thicket really exists in medical biotechnology in Europe. Second, a worldwide patent claim study in the field of genetics, puts the anti-commons theory associated with gene patent claims into perspective as well, and substantiates that the risk that gene patent claims could impede access to a broad range of common genetic tests is mainly a North American problem (with some parallels in Japan). ${ }^{40}$ Third, a recent study provides no further evidence of an emerging anticommons in drug discovery, either. ${ }^{41}$ Last but not least, the suggestion that a thicket might emerge in whole genome sequencing, has lately been severely questioned. ${ }^{42}$

The debate on patent thickets also emerged in the context of agricultural biotechnology. Concerns were expressed in the field of molecular breeding, with the Golden Rice

\footnotetext{
${ }^{37}$ Heller \& Eisenberg [1998] footnote 5.

${ }^{38}$ See Huys et al. [2009] footnote 14.

${ }^{39}$ See E. Van Zimmeren, S. Vanneste \& G. Van Overwalle, Patent Licensing in Medical Biotechnology in Europe: A Role for Collaborative Licensing Strategies?, Leuven, Academic Cooperative Publishers (ACCO), 2011, $145 \mathrm{p}$.

40 See J. Liddicoat, T. Whitton \& D. Nicol, 'Are the gene-patent storm clouds dissipating? A global snapshot' [2015] 33 Nature Biotechnology, 347-352. The results from J. Liddicoat et al. provide evidence that the likelihood that the specific set of patents identified by Huys et al. [2009] footnote 14, could impede genetic testing on a global scale is remote, because many of those patents are not currently in force in countries other than the US.

${ }^{41}$ J. Nielsen, D. Nicol, J. Liddicoat, 'Sharing the Burden in Australian Drug Discovery and Development: Collaborative Trends in Translational Research’ [2014] Intellectual Property Quarterly, 181, 209.

${ }^{42}$ W. Nicholson Price II, 'Unblocked Future: Why Gene Patents Won't Hinder Whole-Genome Sequencing and Personalized Medicine Unblocked Future: Why Gene Patents Won't Hinder Whole-Genome Sequencing and Personalized Medicine' [2012] 33 Cardozo Law Review.
} 
technology as a poster child story, said to be covered by some 70 patents. ${ }^{43}$ Concerns were also voiced in the context of conventional plant breeding in view of the exponential growth of patents claiming native plant traits. ${ }^{44}$ It was argued that the need to assemble multiple traits in one plant variety may well lead to a patent thicket, resulting in restricted access to genetic variation. ${ }^{45}$ Access to variation is essential for breeders for the development of new plants and food security in the long run. ${ }^{46}$ Some empirical work has been carried out to investigate the emergence of a patent thicket in agriculture, ${ }^{47}$ and some recent experiences seem to signal that the problem is non-existing, ${ }^{48}$ but broader patent landscaping studies would be welcome to confirm or deny the existence of a patent thicket in the agricultural field.

Overlooking the past and present, there does not seem to be wide and strong evidence that the rise of patents in the life sciences leads to devastating patent thickets, frustrating the use of technology and ultimately leading to a tragedy of the anti-commons. ${ }^{49}$ So, may be time has come to put this alluring metaphor, which intensely dominated the (academic) debate for the last 15 years, to rest in the future.

\section{Patent pools and clearinghouses. Concept and present-day working examples}

Under the assumption that an anti-commons problem might occur, various strategies have been suggested to mitigate the alleged hindering effect of patent thickets and facilitate access over the past decade. Several private and public ordering approaches have been put forward to deal with the perceived quagmire of patent rights recognizing the (positive) function of the patent system to serve as an incentive and focusing on remedies to tackle some of its (potential, negative) effects (see Table 1) ${ }^{50}$ Our research focused on the role of contractual, collaborative rights organizations in mediating the use of patents in the life sciences.

\footnotetext{
${ }^{43}$ See G. Graff and D. Zilberman, 'Towards an Intellectual Property Clearinghouse for Agribiotechnology' [2001] 3 IP Technol. Today, 1-12; G. Graff, S.E. Cullen, K. J. Bradford, D. Zilberman, \& A. B. Bennett, 'The Public-Private Structure of Intellectual Property Ownership in Agricultural Biotechnology' [2003] 21 Nature Biotechnol., 989-995.

${ }^{44}$ Ibid.

${ }^{45}$ Ibid.

${ }^{46}$ N. Louwaars, H. Dons, G. Van Overwalle, H. Raven, A. Arundel, D. Eaton \& A. Nelis, Breeding Business. The Future of Plant Breeding in the Light of Developments in Patent Rights and Plant Breeder's Rights (Study on request of the Netherlands Ministry of Agriculture, Nature and Food Quality), Wageningen, Centre for Genetic Resources (CGN) - Wageningen University and Research Centre, 2009, (CGN Rapport 2009-14 EN), 27 and the references cited there (available at http://www.wageningenur.nl/nl/show/Breeding-Business.htm, last visited October 20, 2015.

${ }^{47}$ Louwaars et al [2009] footnote 46. The report points to the development of large patent portfolios of more or less overlapping claims.

${ }^{48}$ Some contra-indication for the existence of a patent thicket for native traits can be deduced from an elucidation on the e-licensing platform from Syngenta, see further Section 4.1. (and footnote 114).

${ }^{49}$ Also see B. Depoorter \& S. Vanneste, 'Putting Humpty Dumpty Back Together: Experimental Evidence of Anticommons Tragedies’ [2004] 3 Journal of Law, Economics \& Policy 1.

${ }^{50}$ For more details, see 'Section 1. Introduction' of the present chapter.
} 


\begin{tabular}{|c|c|c|c|}
\hline \multirow{8}{*}{$\begin{array}{l}\text { Mechanisms to facilitate } \\
\text { access and use } \\
\text { of patent protected subject } \\
\text { matter }\end{array}$} & \multirow{3}{*}{\multicolumn{2}{|c|}{$\begin{array}{l}\text { Public ordering } \\
\text { solutions }\end{array}$}} & $\begin{array}{l}\text { Narrowing down patentable } \\
\text { subject matter } \\
\text { Strengthening patentability }\end{array}$ \\
\hline & & & \\
\hline & & & $\begin{array}{l}\text { Introduction wider research } \\
\text { exemption and breeder's } \\
\text { exemption in patent law }\end{array}$ \\
\hline & \multirow{5}{*}{$\begin{array}{l}\text { Private } \\
\text { ordering } \\
\text { solutions }\end{array}$} & \multirow[t]{2}{*}{ Conventional } & Bilateral licences \\
\hline & & & Cross licences \\
\hline & & \multirow[t]{3}{*}{ New } & Patent pool \\
\hline & & & Clearinghouse \\
\hline & & & Open source \\
\hline
\end{tabular}

Table 1. Models facilitating access and use (based on G. Van Overwalle [2009], footnote 15)

\subsection{Patent pools}

Before discussing past and present patent pools in the life sciences field, let us first succinctly bring to mind the notion of patent pools, for the non-informed reader.

\subsubsection{Concept}

The term 'patent pool' has acquired different meanings. ${ }^{51}$ In its widest sense a patent pool refers to a loose collection of patents held by different patent owners. In a more narrow sense, a patent pool points to an agreement between two or more patent owners to license one or more of their patents to one another, and to license them as a package to third parties who are willing to pay the royalties that are associated with the license. Licenses are provided to the licensee, either directly by the patentee, or indirectly through a new entity that is specifically set up for the administration of the pool (see Figure 2).
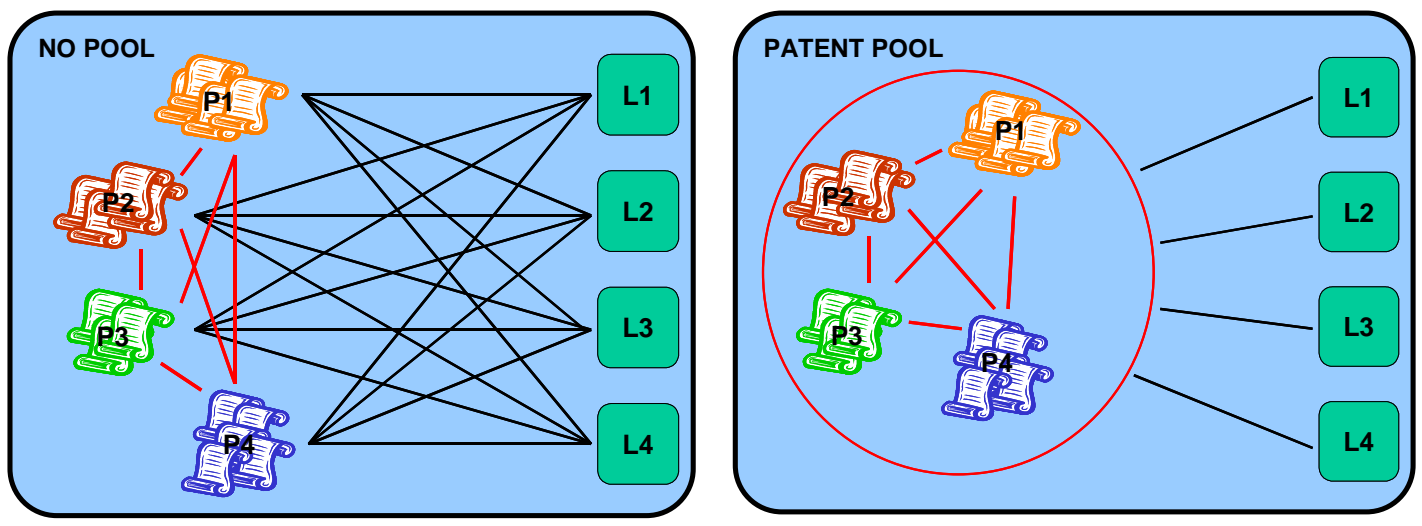

Figure 2. Comparative illustration of the different licenses needed in the absence or presence of a patent pool. P1-P4 represents the patent holders. L1-L4 represents the licensees. In the absence of a patent pool, licensees have to enter into negotiations with all the patent holders, which is a time consuming and expensive process. By contrast, in the presence of a patent pool licensees turn to the patent pool for

${ }^{51}$ See G. Van Overwalle [2010] footnote 15 and the references cited there. 
acquiring the rights as one package, which results in simplification and a significant reduction of transaction costs. ${ }^{52}$

Patent pools may have significant benefits. ${ }^{53}$ In a nutshell, pools may eliminate stacking licenses, reduce licensing transaction costs through the introduction of a system of 'one stop licensing' for non-member licensees, decrease patent litigation and contribute to the institutionalized exchange of technical information that is not covered by patents, through a mechanism for sharing technical information relating to the patented technology, which would otherwise be kept as a trade secret. As well as providing a possible solution to the problem of patent thickets, the creation of a patent pool might also stimulate funding for research and development, benefiting all partners in the pool.

Patent pools might also carry some risks. In brief, pools might shield invalid patents and entail inequitable remunerations. Additionally, patent pools might cover for a cartel and, subsequently, have anti-competitive effects.

Patent pools are not new, having been used occasionally but regularly since the nineteenth century. ${ }^{54}$ The first licensing pool was established in 1856 among members of the sewing machine industry. A further prominent example of an early patent pool is the 1917 aircraft pool that was formed between almost all US aircraft manufacturers. This patent pool was crucial to the US government entering World War I.

In the 1990s the patent pool model gained wide interest in the ICT-sector and several pools with worldwide coverage were formed. In contrast to the early patent pools, those modern pools usually cover relevant patents for one particular standard, rather than covering all patents of an industry. Further, their licensing rules are more complex than those of the early licensing pools. A key example of a modern patent pool in the ICT area is the pool related to the digital video compression standard known as MPEG-2. Another trendsetting patent pool of the 1990s is the DVD pool.

\subsubsection{Life sciences}

Although transplanting the pool concept from ICT to the life sciences was unlikely to be straightforward and was expected to be more than simple cutting and pasting, various patent pools have been set up in this field over the last years.

A patent pool in the health care field which gained wide attention is the Medicines Patent Pool (MPP). ${ }^{55}$ (see Table 2). Founded in 2010, the MPP is a voluntary, UN-backed pool that aims to lower the prices of HIV medicines in low and middle income countries and facilitate the development of better-adapted HIV medicines, such as simplified 'fixeddose combinations' and special formulations for children. ${ }^{56}$ The MPP pool is a postproduct pool, covering fragmented patents for a few particular diseases, rather than a pre-

\footnotetext{
${ }^{52}$ Reprinted from B. Verbeure et al. [2006] footnote 15, at 115 and 116.

${ }^{53}$ See G. Van Overwalle [2010] footnote 15 and the references cited there.

${ }^{54}$ See G. Van Overwalle [2010] footnote 15 and the references cited there.

55 See http://www.medicinespatentpool.org/ (last visited October 20, 2015). The author of the present chapter acted as an advisor to the Extended Expert Consultation elaborating the UNITAID Medicines Patent Pool Initiative at the time of its establishment in 2008.

${ }^{56}$ See http://www.medicinespatentpool.org/ (last visited October 20, 2015).
} 
product platform covering all patents of an industry. ${ }^{57}$ MPP negotiates licenses with relevant patent holders and then sublicenses the patented medicines to generics manufacturers to develop, produce and sell medicines in agreed-upon developing countries under well-defined terms (see Figure 3). ${ }^{58}$ The licenses are not provided directly by the patentee, but indirectly through the MPP which is specifically set up for the administration of the pool. ${ }^{59}$

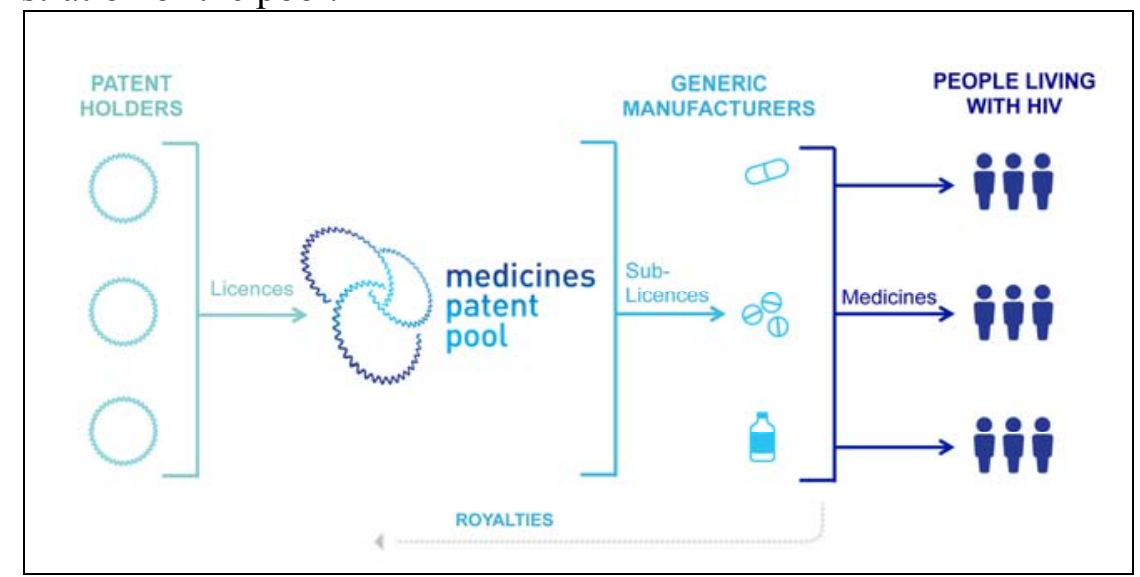

Figure 3. MPP: an indirect licensing pool ${ }^{60}$

A less successful biomedical patent pool was the Severe Acute Respiratory Syndrome (SARS) corona virus pool, supported by the World Health Organization (WHO) ${ }^{61}$ Even though the relevant patent holders had been identified and agreement had officially been gained by the signing of a letter of intent, the pool is no longer actively being pursued, because with no further outbreaks of SARS, the economic driver for the formation of such a pool has been removed. ${ }^{62}$

An instructive patent pool in the field of agriculture is the Golden Rice pool. The scientist Potrykus succeeded in genetically enriching rice grains with $\beta$-carotene ${ }^{63}$ and

${ }^{57}$ Cf. B. Verbeure [2009] footnote 15.

${ }^{58}$ At present, MPP holds licenses for 12 antiretrovirals from six patent holders, and collaborates with 10 generic partners who have distributed 2.18 billion doses of HIV medicines in 117 countries. See Medicines Patent Pool, Working Today for the Treatments of Tomorrow. Annual Report 2014 (available at http://www.medicinespatentpool.org/wp-content/uploads/MPP_Annual_Report_2014_web.pdf, last visited October 20, 2015).

${ }^{59}$ The MPP initiative also encompasses the MPP Patent Status Database collecting data on patented HIV medicines, formulations and combinations (See http://www.medicinespatentpool.org/patent-data/ (last visited October 7, 2015).

${ }^{60}$ See http://www.medicinespatentpool.org/ (last visited October 7, 2015).

61 See C. E. Correa, 'IP Fragmentation and Patent Pools: the SARS Case', in Gene Patents and Collaborative Licensing Models, G. Van Overwalle (ed.), Cambridge, CUP, 2009, 42-49; J. Simon, 'Dealing with Patent Fragmentation: The SARS Patent Pool as a Model', in Gene Patents and Public Health, G. Van Overwalle (ed.), Brussel, Bruylant, 2007, 115-120; J. H. M. Simon, E. Claassen, E., C. E. Correa, A. D. M. E. Osterhaus, 'Managing severe acute respiratory syndrome (SARS) intellectual property rights: the possible role of patent pooling' [2005] Bulletin of the World Health Organization, 707-710.

${ }^{62}$ E. van Zimmeren et al. [2011] footnote 15.

${ }^{63}$ P. Beyer, S. Al-Babili, X. Ye, P. Lucca, P. Schaub, R. Welsch \& I. Potrykus, 'Golden Rice: Introducing the Beta-Carotene Biosynthesis Pathway into Rice Endosperm by Genetic Engineering to Defeat Vitamin A Deficiency' [2002], 132 The Journal of Nutrition, 506. 
wanted to transfer the Golden Rice materials to developing countries for further breeding in order to introduce the trait into local varieties that are consumed in these countries. The key patent holders were approached and a voluntarily agreement was reached that allowed Potrykus to grant licenses with the assistance of the intermediate legal entity Greenovation, acting as an administrator. ${ }^{64}$ Conceived as a post-product pool covering the essential patents to produce Golden Rice, it is not clear why the pool is not yet up and running at present. Insiders suggest that this might relate to the long and cumbersome marketing authorization procedure, and even more so, to the current opposition in civil society to embrace genetically modified plants. ${ }^{65}$

\subsection{Patent clearinghouses}

Before setting out on a tour d'horizon (re)assessing the objectives and performance of past and present day patent clearinghouses in the life sciences area, let us first briefly recall the notion of clearinghouses in general, and patent clearinghouses in particular, for the non-expert reader.

\subsubsection{Concept}

The term 'clearinghouse' is derived from banking institutions and refers to the mechanism by which cheques and bills are exchanged among member banks to transfer only the net balances in cash. Nowadays the concept has acquired a broader meaning that refers to any mechanism by which providers and users of goods, services and/or information are matched (see Figure 4). ${ }^{66}$
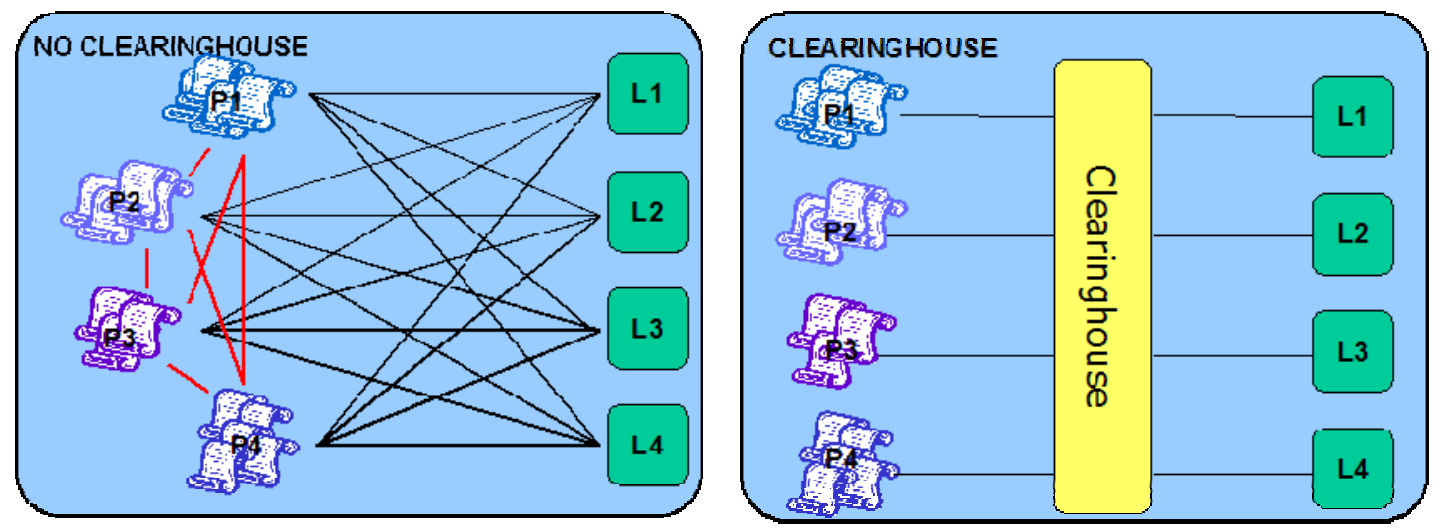

Figure 4. Comparative illustration of the different licenses needed in the absence or presence of a clearinghouse. P1-P4 represents the patent holders. L1-L4 represents the licensees. In the absence of a

${ }^{64}$ See http://www.goldenrice.org/index.php (last visited November 17, 2015). Also see G. Graff \& D. Zilberman [2001] footnote 43; G. Graff et al. [2003] footnote 43, at 989; R. Parish \& R. Jargosch, R., 'Using the Industry Model to Create Physical Science Patent Pools among Academic Institutions' [2003] 15 J. Ass'n U. Tech. Managers 65

${ }^{65}$ It has been argued that NGO's oppose the marketing of Golden Rice. However, Dr. Moore, co-founder of Greenpeace, has undergone a change of heart and now supports the Golden Rice initiative, see http://www.allowgoldenricenow.org/ (last visited November 18, 2015).

${ }^{66}$ See G. Van Overwalle [2010] footnote 15 and the references cited there. 
clearinghouse, licensees have to enter into negotiations with all the patent holders. In the presence of a clearinghouse, licensees turn to the clearinghouse entity for acquiring the rights.

Clearinghouses facilitate access to patented innovations by centralizing scattered patent rights. Based on the various functions a clearinghouse may fulfill, four main types can be distinguished.$^{67}$ Two models merely provide access to (patented or otherwise protected) information: the information clearinghouse and the technology exchange clearinghouse. Two more elaborate models provide access and also standardize the use of the (patented) inventions: the standardized licenses clearinghouse and the royalty collection clearinghouse.

The information clearinghouse provides a mechanism for exchanging technical information and/or information that is related to the IP status of that information. Examples of information clearinghouses include general patent search sites, either freely accessible, such as Espacenet from the European Patent Office (EPO) ${ }^{68}$, or fee-based, like Thomson. ${ }^{69}$ A new initiative is Lens,${ }^{70}$ offering a free, fully text-searchable database of patents worldwide, integrated with scholarly and technical literature along with regulatory and business data. Lens is established with the support of Cambia and the Queensland University of Technology.

The technology exchange clearinghouse is inspired by the internet-based business-tobusiness (B2B) model and provides an information service that lists the available technologies to allow technology owners and/or buyers to initiate negotiations for a license. Additionally, it may provide more comprehensive mediating and managing facilities. It is important to underline that actual access to the patented inventions is not usually granted by the technology exchange clearinghouse, but by the individual patent holder after one-to-one licensing negotiations have taken place with the licensee. These negotiations are, however, based on the information on the inventions which was provided by the clearinghouse. Although the technology-exchange clearinghouse model is generally cheap to maintain and generates only low operating costs, it might be difficult to bring together the critical mass of patents that would be needed to turn platforms of this type into useful tools.

The standardized licenses clearinghouse provides access to and standardizes licenses for the use of protected inventions. A clearinghouse may offer 'standard' licenses. 'Standard' by no means signifies 'one size fits all' or absence of variability. 'Standard' means a preset license with options that vary according to the broad features of the rights. Standard licenses can be differentiated as to the nature of the user, the objective of the use and the profile of the eventual product to be developed by the licensee. The access to licenses can be arranged by a portal through which licensors and licensees can use a simple interface, with drop-down menus and standard questions, enabling the creation of a customized agreement, tailored to fit the large variety of circumstances in patent

\footnotetext{
${ }^{67}$ See G. Van Overwalle [2010] footnote 15 and the references cited there. The fifth type mentioned in Van Overwalle [2010] more in particular the open source clearinghouse, will not be discussed here.

${ }^{68}$ See http://worldwide.espacenet.com/ (last visited October 20, 2015).

${ }^{69}$ See http://info.thomsoninnovation.com/en/features/search (last visited October 20, 2015).

${ }^{70}$ See https://www.lens.org/lens/ (last visited October 20, 2015). The Lens initiative grew out of the Patent Lens initiative, an initiative established alongside the open source BiOS project (http://www.bios.net/daisy/bios/home.html (last visited October 20, 2015) within the framework from Cambia (http://www.cambia.org/daisy/cambia/home.html (last visited October 20, 2015).
} 
licensing Replacing the tailored license by a (customized) standard license agreement would diminish the bargaining costs for individual licenses. A well-known example of a standardized license clearinghouse is Creative Commons (CC). ${ }^{71} \mathrm{CC}$ has already been in operation for a couple of years facilitating the use of copyrighted material, such as music, movies, photos, books, course materials, scientific and medical literature by way of standardized, simplified.

The royalty collection clearinghouse comprises all the functions of the information clearinghouse, the technology exchange clearinghouse and the standardized licenses scheme. In addition to these functions, the royalty collection clearinghouse sets up a mechanism to collect license fees from users on behalf of the patent holders in return for the access to and use of the inventions. The patent holder is reimbursed by the clearinghouse pursuant to a set allocation formula, which has been negotiated beforehand. Classical examples of royalty collection clearinghouses include copyright societies such as ASCAP (the American Society of Composers, Authors and Publishers ${ }^{72}$ ) or other national agencies. ${ }^{73}$

\subsubsection{Life sciences}

Initial writings focused on patent pools for ICT and copyright collecting societies for music. For quite some time now, the academic debate has been taken further and has examined those models for use in the life sciences.

\section{Information clearinghouses}

A rather new and well appreciated initiative in the agricultural sector is Information and Transparency On-line (PINTO) which has been created with the aim of improving transparency regarding the patent status of plant varieties. Although there are many publicly accessible patent databases, this project provides the link between a plant variety and a patent, information which is currently not available elsewhere. ${ }^{74}$

\section{Technology exchange clearinghouses}

Specific health care technology exchange platforms have existed for quite some time. A typical example is Pharmalicensing ${ }^{75}$ an online platform providing online partnering support that enables companies in the biopharmaceutical and biomedical industry to find licensing partners and conclude licensing contracts.

A new kid on the block in the health care sector is WIPO Re:Search, an online platform set up under the auspices of the World Intellectual Property Organization (WIPO) in

\footnotetext{
${ }^{71}$ See http://creativecommons.org/ (last visited, October 20, 2015).

${ }^{72}$ See http://www.ascap.com/ (last visited, October 20, 2015).

${ }^{73}$ E.g. Sabam in Belgium (http://www.sabam.be/ last visited, October 20, 2015).

${ }^{74} \mathrm{http}$ ://pinto.euroseeds.eu/ (last visited October 12, 2015). The main feature of PINTO is the search tool function which allows users to look through the database on the basis of a number of search criteria such as variety denomination, species, patent number, patent holder or keyword.

${ }^{75}$ See http://www.worldpharmalicensing.com/ (last visited October 7, 2015).
} 
collaboration with BIO Ventures for Global Health (BVGH) ${ }^{76}$ The primary objective of WIPO Re:Search is to catalyze new research and development for neglected tropical diseases (NTDs), malaria and tuberculosis. For achieving this, WIPO Re:Search has established an independent administrator entity, the so-called Partnership Hub managed by a Partnership Hub Administrator (in casu BVGH) where users can obtain additional, confidential information about any patent. ${ }^{77}$ (See Figure 5). Patent holders grant users royalty-free non-exclusive licenses to their IP (including access to know-how and data, for research and development), but access is subject to individually negotiated licensing agreements between patent holders and users. ${ }^{78}$ Although the Partnership Hub can facilitate research agreements, all discussions on concluding a licensing agreement and any preliminary arrangements (confidentiality and other types of agreements) are handled directly by the patent holder and potential user. ${ }^{79}$ So, WIPO Re:Search is a cooperative, voluntary, pre-product technology exchange arrangement between IP holders and users, united by a common set of principles and objectives, but each acting on their own. WIPO Re:Search indeed creates "an open innovation platform through which public and private sector entities can share IP", be it on individually negotiated terms. ${ }^{80}$

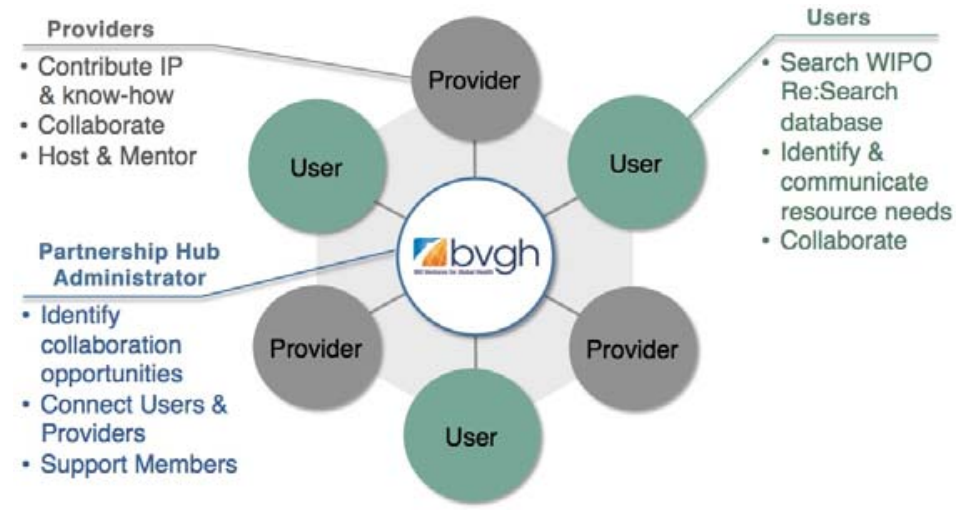

Figure 5. WIPO Re:Search: a technology partnering clearinghouse [http://www.bvgh.org/Portals/0/Reports/2012 2013 wipo rs storybook.pdf, last visited November $\overline{18}, 2015]$

Specific agricultural clearinghouses include Public Intellectual Property Resource (PIPRA), a voluntary collaboration between universities, foundations and non-profit

\footnotetext{
${ }^{76}$ See WIPO Re:Search. Sharing Innovation in the Fight Against Neglected Tropical Diseases. Guiding Principles, 2011 (available at http://www.wipo.int/research/en/, last visited, October 12 2015). The initial pool (http://www.ntdpool.org/, discussed in E. van Zimmeren et al. [2011] footnote 15) is no longer active.

${ }^{77}$ For more details, see Annex 3 of the WIPO Guiding Principles, footnote 67.

${ }^{78}$ For more details, see Annex 3 of the WIPO Guiding Principles, footnote 67.

79 At the close of 2014, 82 collaborations were in place between members, including 38 established in 2014, see WIPO Re:Search, 2014 Partnership Hub Report. Catalyzing Partnerships for Global Health (available at http://www.wipo.int/export/sites/www/research/en/docs/bvgh research report 2014.pdf, last visited October 12, 2015). It is further interesting to note that providers will not make any claims to rights in new IP, materials or derivatives of materials generated by a user under a license agreement made pursuant to membership in this WIPO Re:Search, but may require such user not to assert such new IPRs against the provider. For products resulting from licenses through the Consortium, all users are encouraged to provide licenses for these products on a royalty-free basis for use and sale in all LDCs.

${ }^{80}$ Ibidem.
} 
research institutions to make dispersed agricultural technologies more easily available for humanitarian use. ${ }^{81}$ Much has changed over the decade since PIPRA was first conceived. There has been a movement toward viewing IP less as a block to innovation and more as a high, but surmountable, transaction cost; IP-related transaction costs have been put into perspective amidst other costs of developing genetically modified crops (including regulatory, technical, marketing, and political issues). ${ }^{82}$ Since its inception, PIPRA moved away from identifying their core function as a patent clearinghouse and toward a model providing services focused on research and analysis, agreement negotiation and drafting, lab services and international workshops.

A totally new clearing initiative in the agricultural sector is the International Licensing Platform for vegetable plant breeding (ILP Vegetable), voluntarily launched in November 2014 by a group of breeding companies. ${ }^{83}$ The main objective of IPL Vegetable is to guarantee worldwide access to patents that cover crucial vegetable plant traits that are currently covered by patent claims by ILP Vegetable member companies. ${ }^{84}$ Central in the set-up of IPL Vegetable is the principle of membership and reciprocity: the willingness to become a member and put one's patents on the platform is a key condition to be allowed access to all patents on the platform ${ }^{85}$ (see Figure 6). The ILP Vegetable mechanism, provides an information service listing available patents to allow technology owners and/or buyers to initiate one-to-one bilateral license negotiations. Indeed, license negotiations are first conducted on a bilateral basis and are expected to take place on 'fair and reasonable' terms. ${ }^{86}$ During the bilateral negotiations, members may choose to make use of the standard license provided for by ILP Vegetable. If bilateral negotiations fail and members do not reach a consensus within a period of three months after the start, ILP provides comprehensive mediating facilities. The case can be submitted to the secretary of the ILP Vegetable and later on to a group of independent experts, who will take a decision based on a so-called baseball procedure. ${ }^{87}$

\footnotetext{
${ }^{81}$ See R. C. Atkinson, R. N. Beachy, G. Conway, F. A. Cordova, M. A. Fox, K. A. Holbrook, D. F. Klessig, R. L. McCormick, P. M. McPherson, H. R. Rawlings III, R. Rapson, L. N. Vanderhoef, J. D. Wiley, C. E. Young, 'Public Sector Collaboration for Agricultural IP Management' [2003] 301, Science 174-175. Also see A. B. Bennett \& S. Boettiger, 'The Public Intellectual Property Resource for Agriculture. A Standard License Public Sector Clearinghouse for Agricultural IP', in Gene Patents and Collaborative Licensing Models, G. Van Overwalle (ed.), Cambridge, CUP, 2009, 135-142.

${ }^{82}$ See http://www.pipra.org/ (last visited October 21, 2015).

83 Eleven breeding companies were the founding fathers of ILP Vegetable, comprising both listed companies and family businesses from Switzerland, Germany, Japan, France and the Netherlands (namely (Agrisemen, Bayer, Bejo, Enza, Holland-Select, Limagrain, Limgroup, Pop Vriend, Rijk Zwaan, Syngenta and Takii)v(see http://www.ilp-vegetable.org/about-ilp and http://www.ilp-vegetable.org/members/ (last visited October 14 2015).

${ }^{84} \mathrm{See}$ http://www.ilp-vegetable.org/ (last visited October 14, 2015). The latest version of the patents offered for licensing dates from October 5, 2015 and can be found in the Patent Register (see http://www.ilp-vegetable.org/patents/, last visited October 14, 2015).

${ }^{85}$ Membership is open to all interested parties, regardless of whether they own patents or not. The annual membership fees are based on the number of full term employees of the company and its affiliates in the year membership is applied for (see http://www.ilp-vegetable.org/about-ilp and http://www.ilpvegetable.org/members/ (last visited October 14 2015).

${ }^{86}$ See http://www.ilp-vegetable.org/patents/ (last visited October 14, 2015).

${ }^{87} \mathrm{In}$ concreto the procedure unfolds as follows. Both non-agreeing members will submit their license fee proposal to the secretary of the ILP Vegetable. After receiving figures from both members, the secretary exchanges the two proposals between the two members involved with the possibility to come to an
} 


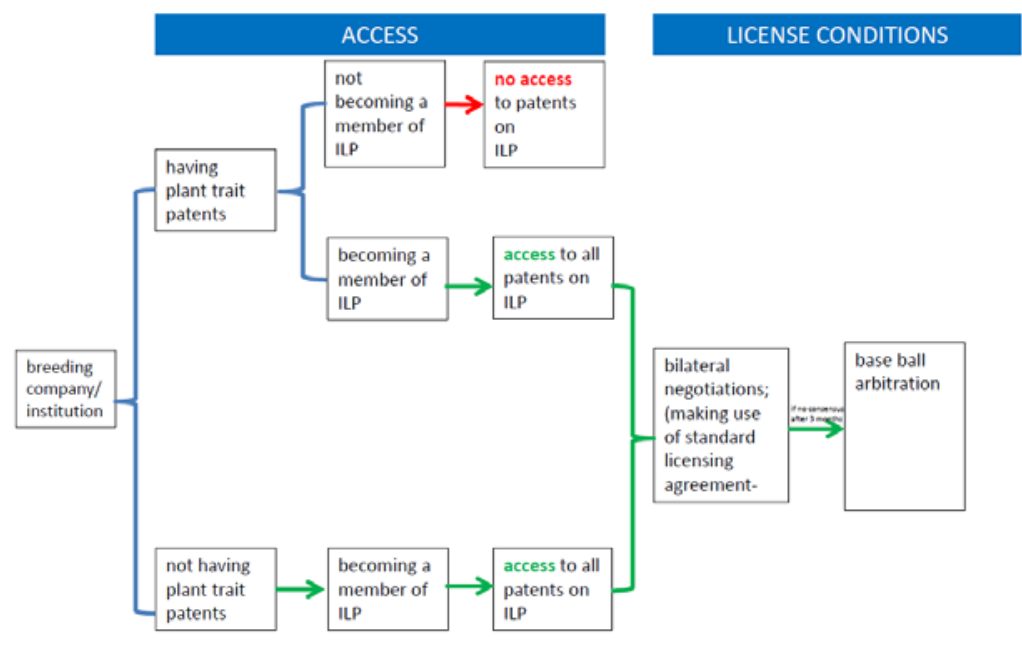

Figure 6. International Licensing Platform (ILP) Vegetable

\section{Standardized clearinghouses}

Standardized clearinghouses in the life sciences are still relatively young. Science Commons is an initiative expanding the use of standardized Creative Commons (CC) licenses to scientific and technical research. ${ }^{88}$ A project within Science Commons which is slowly emerging is the Biological Materials Transfer (BMT) Project. The BMT Project aims at "building the clearinghouse for research tools". ${ }^{89}$ A first initiative under the BMT Project is the Biological Materials Transfer Agreement (BMTA) Project which aims at developing standard, modular contracts to lower the costs of transferring physical biological materials such as DNA, cell lines, model animals, antibodies, etc. among nonprofit institutions as well as between non-profit and for profit institutions. ${ }^{90}$ Standard terms are being developed with regard to the scope of the use of the material (commercial/non-commercial, etc.), but standard terms do not seem to be available (as yet) with regard to license fees. A second initiative under the BMT Project relates to a prototype project called GreenXchange, fueling so-called public patent licenses. Under the GreenXchange project, the goal is to encourage patent holders to make their patent

agreement within three weeks. If no agreement can be reached, the decision is referred to a group of independent experts, who will choose the most reasonable proposal. Subsequently, a Standard License Agreement including the chosen proposal will be executed. It is argued that this system encourages both parties to propose reasonable positions, because an unreasonable position will be rejected in favour of a more reasonable proposal. The cost for the baseball arbitration must be paid by the member whose proposal has not been selected by the independent experts (see http://www.ilp-vegetable.org/about-ilp/licensingsystem/ and http://www.ilp-vegetable.org/q-and-a/q7.html (last visited October 14, 2015).

88 Science Commons was recently integrated with Creative Commons, see https://creativecommons.org/science/ (last visited October 14, 2015).

${ }^{89} \mathrm{See}$ http://sciencecommons.org/projects/licensing/ (last visited October 9, 2015).

90 See http://sciencecommons.org/projects/licensing/details/ (last visited October 14, 2015); also see http://mta.sciencecommons.org/agreements/sc-ou/2.0/ (last visited October 14, 2015). Also see T. Nguyen, 'The Science Commons Material Transfer Agreement Project. A Standard License Clearinghouse?' in Gene Patents and Collaborative Licensing Models, G. Van Overwalle (ed.), Cambridge, CUP, 2009, 14350 . 
portfolio available for licensing through public license offers, where the offer is openly and can be accepted by anyone on a non-discriminatory basis and without additional negotiation, ${ }^{91}$ in other words where it is expected that anyone who can agree to it is empowered to accept without further negotiation. ${ }^{92}$ However, practical details on how this mission statement will be implemented are lacking at present. Or is this initiative rather fading out than coming up $?^{93}$

Another rather new initiative in the health care sector is set up by MPEG LA, renown administrator of patent pools, ${ }^{94}$ who established a molecular diagnostics licensing clearinghouse in April 2010, known as Librassay or 'licensing supermarket'. Librassay's aim is to aggregate patent rights for existing and emerging tests that could lead to personalized treatment (e.g. in relation to cancer, cardiovascular disease, diabetes, neurological disorders and various hereditary conditions such as hearing loss) and to license those patents non-exclusively for diagnostic use at preset annual fees per patent and royalty rates. ${ }^{96}$ Patent owners can enter into a commitment to provide their patents in the diagnostic field to Librassay for a minimum of 5 years. Patent owners retain rights for research, education and drug development carried out by them or on their behalf. Patent owners have the option of delegating the responsibility and costs associated with patent maintenance fees and with continuing patent prosecution to MPEG LA. MPEG LA assumes the cost for any enforcement actions that might be necessary based on the interests of the patent owners and licensees enrolled in the supermarket. Further research is needed to assess whether Librassay covers the patents most relevant for personal medicine. ${ }^{97}$

On the agricultural front, recently some agriculture companies established e-licensing platforms. One such platform has been set up by Syngenta. ${ }^{98}$ The Syngenta platform offers breeders and research institutes guaranteed access to a wide portfolio of patented native traits and enabling technologies present in their commercial vegetable varieties. ${ }^{99}$ A key feature of the platform is royalty free access for licensed traits during development and breeding of new varieties and royalty payment at preset terms if the newly-developed

\footnotetext{
${ }^{91}$ See https://wiki.creativecommons.org/wiki/CC Public Patent_License (last visited October 14, 2015).

92 See http://sciencecommons.org/projects/patent-licenses/ (last visited October 14, 2015).

93 This observation was uttered by a former CC collaborator during the Joseph Kohler Symposium on 'Intellectual Property on Plants' at the Humboldt University in Berlin, October 30, 2015, where the author presented a paper on this issue.

${ }_{94} \mathrm{http}: / /$ www.mpegla.com/ (last visited October 21, 2015).

95 https://www.librassay.com/ (last visited October 21, 2015). Also see E. van Zimmeren et al. [2011] footnote 15.

96 See Librassay ${ }^{\circledR}$ Patent Portfolio License Summary, September 12, 2013 (available at https://www.librassay.com/RequestLicense.aspx, last visited October 27, 2015). In sum, the "basic annual fee" amounts to $2.500 \$$ per licensed patent up to a maximum of $12.500 \$$ per year. The royalty follows a preset formula (royalty rate $\mathrm{x}$ income from sales ("collectibles") of a given royalty bearing product or use) and a schedule of royalty rates based on patent count.

${ }^{97}$ Personal communication Isabelle Huys, November 42015.

98 See http://www3.syngenta.com/global/e-licensing/en/e-licensing/Pages/home.aspx (last visited October 20, 2015).

${ }^{99}$ See http://www3.syngenta.com/global/e-licensing/en/e-licensing/Catalog/Pages/Catalog.aspx (last visited October 20, 2015).
} 
and commercialized variety contains the patented trait. ${ }^{100}$ In principle more favorable conditions than the preset ones are not available by contacting outside of the e-licensing system. However, bilateral agreements may be used in specific cases when a deal entails more than a monetary retribution. ${ }^{101}$ The Syngenta initiative is an impressive effort to establish a fully fletched standardized licensing platform in the sense that it organizes access to patented subject matter on in advance defined and standardized terms and that it provides access to and standardizes licenses for the use of protected inventions. It remains to be seen to what extent users consider the royalty setting fair and reasonable, and whether the platform is effectively used.

Another agricultural e-licensing platform is set up by Enza Zaden. ${ }^{102}$ The Enza Zaden platform offers a selection of (trait) technologies and accompanying varieties, relating to lettuce, cucumber and melon. ${ }^{103}$ The standard terms include a non-exclusive, royaltybearing license to use the patented (native trait) technology, for research, breeding and commercial purposes. ${ }^{104}$ Unfortunately, details on the royalty terms are lacking, ${ }^{105}$ so it cannot be verified whether Enza is indeed a standardized licensing platform, offering access at predefined financial terms.

\section{Royalty collecting clearinghouses}

At present, no examples of a royalty collection clearinghouse seem exist in the field of the life sciences. The Global Bio-Collecting Society (GBS) ${ }^{106}$ was a praiseworthy attempt to design a royalty collection clearinghouse model in agriculture, but never moved beyond the conceptual stage.

\section{Present-day patent pools and clearinghouses. Critical assessment}

Amongst the many themes which have governed academic discourse on collaborative licensing over the last decade, three themes have been singled out here for further inquiry. More in particular, we will examine the objectives (See 4.1.), the institutional design (See 4.2.) and the impact on innovation (See 4.3.) of collaborative licensing

\footnotetext{
100 See http://www3.syngenta.com/global/e-licensing/en/e-licensing/About/Pages/About.aspx (last visited October 20,2015). The procedure to license patented native traits and enabling technologies unfolds in four steps. In a first step users are invited to search the Syngenta catalog by accessing the e-license website. When a user clicks on a trait or technology of his choice, detailed information on the technical features, the standard financial terms, the patent status and the list of commercial Syngenta varieties that contain the patented native traits appear. Further steps include filling out the standard agreement. 101 See http://www3.syngenta.com/global/e-licensing/en/e- licensing/About/Pages/Frequentlyaskedquestions.aspx (last visited October 20, 2015). This has been confirmed by a participant from thee seed industry during the Joseph Kohler Symposium on 'Intellectual Property on Plants' at the Humboldt University in Berlin, October 30, 2015, where the author presented a paper relating to this issue.
${ }_{102}$ See http://www.enzazaden.com/elicensing/ (last visited October 20, 2015).
${ }^{103}$ See http://www.enzazaden.com/elicensing/catalog/ (last visited October 20, 2015).
${ }^{104}$ See http://www.enzazaden.com/elicensing/getlicence/ (last visited October 20, 2015).
105 For further information and execution of a standard license agreement, interested parties are invited to contact Enza, see http://www.enzazaden.com/elicensing/getlicence/ (last visited October 20, 2015)
${ }^{106}$ P. Drahos, 'Indigenous Knowledge, Intellectual Property and Biopiracy: Is a Global Bio-Collecting Society the Answer?' [2000] 20 EIPR, 245. 
mechanisms. These elements vary considerably between the patent pools and clearinghouses under study (see Table 2). ${ }^{107}$

\subsection{Changing objectives. Towards multi-purpose models}

From their creation as a response to emerging patent thickets, the direct goal of both patent pools and clearinghouses has been to facilitate access to protected creations and innovations by centralizing scattered patent rights. ${ }^{108}$ During the last decade, two tendencies can be witnessed, resulting in a movement away from this core objective.

A first tendency is the worldwide upsurge of 'patent aggregators'. Patent aggregation describes any activity where patents that were previously owned by a number of different parties, are brought under the control of a single actor or entity. ${ }^{109}$ Entities actively aggregating patents are usually said to include patent pools, patent brokers, practising entities and non-practising entities (patent monetisation entities). ${ }^{110}$ It has been suggested that many types of patent aggregators are beneficial and contribute to creating markets for technology, thus solving market inefficiencies and improving incentives to innovate; however, individual behaviour and specific services offered can have negative welfare implications and should be judged on a case-by-case basis. ${ }^{111}$ As many patent aggregator web sites and business models promoting on-line licensing of patents have unfolded during the last decade, collaborative licensing models such as patent pools and clearinghouses have refocused on providing additional services, going beyond the simple centralization of patent rights. Exemplary in this regard is PIPRA, who has moved away from simply offering patents, to providing IP analysis (offering broad landscapes or analyses focused on particular technologies), biotechnology resources (e.g. the PIPRA vector), drafting and negotiating agreements, research consortia support (including public-private partnerships), IP management workshops, commercialization strategies to improve technology delivery and IP policy analysis. ${ }^{112}$ A similar, widened, approach can be observed within Science Commons and the Biological Materials Transfer (BMT) Projects.

\footnotetext{
107 The interplay between collaborative licensing mechanisms and standards will not be reviewed here. The interested reader might care to consult K. Maskus and S. A. Merrill (eds), Patent Challenges for StandardSetting in the Global Economy: Lessons from Information and Communication Technology, National Research Council (2013); E. van Zimmeren [2011] footnote 14, 16-17, 485 ff.

108 See G. Van Overwalle [2010] footnote 15.

109 See EPO Economic and Scientific Advisory Board (ESAB), Report on Patent aggregation and its impact on competition and innovation policy, Munich, 25 November 2014 (available at http://www.epo.org/about-us/office/esab/workshops.html, last visited October 23, 2015). Control essentially means the right to decide which party gets access to the patents and under what terms, Ibidem. Patent aggregators are usually distinguished from patent intermediaries. Patent intermediaries are organisations which match supply and demand of individual patents or patent portfolios, possibly in combination with technology or additional know-how, and facilitate patent-based transactions (See N. Ziegler, M. A. Bader \& F. Ruther, Handbook External Patent Exploitation: Motives, Forms, the Role of Intermediaries and a Guideline, St. Gallen: ITEM-HSG, 2011 (available at http://www.bgw-sg.com/wpcontent/uploads/2014/04/Handbook CTI-IPotential final1.pdf, last visited October 23, 2015).

${ }^{110}$ See EPO Economic and Scientific Advisory Board (ESAB), 2014, footnote 96.

${ }^{111}$ See EPO Economic and Scientific Advisory Board (ESAB), 2014, footnote 96.

112 See PIPRA's History and Changes over Time (available at http://www.pipra.org/about/, last visited October 23, 2015).
} 
A second tendency is the growing interest in industry circles for potentially blocking single patents. A tragedy of the anti-commons may not only occur as a result of fragmentation or overlap of patents, but may also arise in case of the emergence of a single, so-called 'blocking' patent. A blocking patent refers to a patent covering (some or more) features which are essential for a certain activity or function. ${ }^{13}$ Some recent collaborative license initiatives bear witness of the aim to facilitate access to single, potentially blocking patents, rather than to collect scattered patent rights. Exemplary in this regard are the Syngenta e-licensing platform, the Enza initiative and, most prominently, the ILP Vegetable platform. ILP Vegetable recognizes that the major problem in the sector is not fragmentation or overlap, since "the number of patents available per species is often one only". ${ }^{114}$ Rather, ILP Vegetable aims at providing guaranteed access to those single patents.

Although collaborative models share a common direct goal - namely to facilitate access by centralizing scattered IP rights or, more recently, to provide guaranteed access to single patents - they may be fueled by different final motivations. Looking at their underlying rationale and ultimate objectives, two major models can be distinguished: market driven models and policy driven models. Market driven ('push') models follow a commercial scenario: usually voluntarily created by private, commercial actors (bottom up), they follow market rules (e.g. market price, reasonable license) in an attempt to cure an efficiency problem. A prominent example here is the ILP Vegetable and the Librassay clearinghouse. Policy driven ('pull') models follow a rather 'idealistic' logic: usually though not necessarily - set up voluntarily or mandatorily by governmental/nongovernmental institutions (top down), they follow government rules (e.g. low price or free license) in an attempt to serve a public policy objective. Key examples include the MPP pool, the Golden Rice pool and the WIPO Re:Search initiative.

It is remarkable to see that market driven actors release their patents free of charge in the context of policy driven models, such as the MPP pool, the Golden Rice pool and the

\footnotetext{
${ }^{113}$ The term 'blocking patent' is not clear and can be used in different ways. In its widest sense, any patent is by definition a blocking patent, as a patent confers upon its proprietor the right to stop others from making, using, offering for sale, selling, or importing the patented invention (See art. 281 TRIPs Agreement). Used in this sense, the notion blocking patent is a tautology. In a more narrow sense, a blocking patent is a patent covering essential features of the invention which cannot be invented around. In its strictest sense, a blocking patent is a patent covering essential features which are licensed in a very restrictive manner. The risk of a blocking position arises if one of the essential technologies is licensed on exclusive terms so third parties cannot have access to part of the technology deemed necessary to manufacture a product. In the present chapter - as in our previous research - the term 'blocking patent' will be used in the second, more narrow, albeit multi-layered sense. See G. Van Overwalle [2009] footnote 15, at 381 .

${ }^{114}$ See e-licensing platform from Syngenta, where the following is said in the FAQ section: "What is your view on stacking multiple native traits? At the moment we don't see the need to handle differently the case of multiple native traits stacked in one variety, as the number of patents available per species is often one only. This may change in the future as the industry practices evolve". However, it is suggested that problems may arise when multiple enabling technology are at play: "Can I get a discount when licensing simultaneously multiple Enabling Technologies? Yes, for enabling technologies a licensee can access two licenses for a discount of $25 \%$ on each of the two license fees to be paid to Syngenta. Whereas, for three or more licenses the licensee will be eligible for a discount of $35 \%$ on each of the license fees actually paid to Syngenta." See http:/www3.syngenta.com/global/e-licensing/en/elicensing/About/Pages/Frequentlyaskedquestions.aspx (last visited October 20, 2015).
} 
WIPO Re-Search initiative. ${ }^{115}$ Recent economic research has looked into the motivation(s) why firms release their patents free of charge in such a context. Four ultimate motives of free patent release approaches have been identified: profit making, cost cutting, innovation catalyzing and technology providing. Firms may obtain valuable technological input for subsequent innovations as well as social benefits in return for their free patent release. ${ }^{116}$ In short, firms may obtain non-monetary benefits from their free patent release on collaborative, policy driven models.

\subsection{Changing institutional design. Towards 'hybrid' models}

Over the last decade, no significant developments can be noted on the institutional set up patent pools and clearinghouses, in terms of their coming into existence. First, collaborative rights models may be established as a result of the voluntary engagement of the patent owners, or as the result of a compulsory licensing mechanism initiated by the government. In the life sciences initiatives under study, voluntary negotiations have been the prevailing mode of initiation. Second, collaborative institutions may be set up by private actors or by governmental institutions. In the life sciences cases under study, some platforms have been initiated by public, governmental institutions, and some others have been set up by private entities (e.g. ILP Vegetable, Syngenta e-licensing, Enza zaden). Third, collaborative models may encompass private and/or public patent holders. From the examples under study, some collaborative licensing models encompass private patent holders (e.g. MPP, Golden Rice, WIPO Re:Search), other initiatives solely include public technology providers (e.g. PIPRA), whereas still others include both public and private technology holders.

No meaningful developments can be observed relating to the management structure, in terms of administering entity, either. A patent pool may be managed directly by the patentee or indirectly through a new entity that is specifically set up for the administration of the pool. ${ }^{117}$ In the clearinghouse model the central entity, acting as a gobetween for patentees and licensees, is a key feature. Most cases under study act through a central entity, apart from the two single-firm initiatives (Syngenta e-licensing and Enza Zaden) who operate via the patent holding firm.

However, interesting institutional changes can be observed when it comes to the relationship between the patent holders involved in a patent pool or clearinghouse. In a patent pool normally strong relations emerge between all patent holders, resulting in a set up agreement amongst all pool members. In contrast, a clearinghouse will most probably not be established by an agreement amongst patent holders, but will come into existence through a series of separate contracts between a central, administering body and an

\footnotetext{
${ }^{115}$ N. Ziegler, O. Gassman \& S. Friesike,'Why do firms give away their patents for free?', World Patent Information, 2013, 1-7.

${ }^{116}$ Ziegler et al. [2013] footnote 115.

117 On the distinction between "direct" and "indirect" licensing, see C. Shapiro, "Setting Compatibility Standards: Cooperation or Collusion', in Expanding the Boundaries of Intellectual Property, R. Dreyfuss, D. L. Zimmerman, \& H. First (eds.), Oxford Univ. Press, 2001, 81-102.
} 
individual patent holder, rather than by an agreement amongst patent holders. ${ }^{118}$ Over the last few years, lesser platforms seem to emerge taking the shape of patent pools in the narrow legal sense, and more 'hybrid' models are created. The MPP deviates from a strict patent pool model, as it does not entail a prior multiparty agreement between all patent owners to license one or more of their patents to one another, but solely encompasses agreements between the patent owners and the pool - acting as an intermediary - after which the pool sub licenses their patents to third parties. ${ }^{119}$ On the other hand, the MPP pool does align itself with the patent pool philosophy, in that it covers relevant patents for the production of one particular disease, rather than acting as a 'supermarket' for a variety of disease related patents. In turn, ILP Vegetable - a clearinghouse at first sight contains a few elements which resemble a patent pool. It is set up as a multiparty agreement between the participating companies, and strongly characterized by a membership principle, possibly creating a club atmosphere. ${ }^{120}$

\subsubsection{Competition law analysis. Level of essentiality}

The qualification as a patent pool, a clearinghouse or a hybrid model is not a frivolous or semantic exercise, but is highly relevant for two reasons. First, depending on the type of collaborative licensing platform, competition law issues are entailed. In an attempt to deal with any potential anticompetitive effects of multiparty licensing agreements and the preclusion of cartels, the European Commission has established some rules. Nowadays, the major competition rules relating to technology licensing are laid down in the Commission Block Exemption Regulation (EU) No. 316/2014 on Technology Transfer Agreements $^{121}$ and the Guidelines on the application of Article 101 of the TFEU to

\footnotetext{
118 See G. Van Overwalle [2010] footnote 15, at 305-324. In this regard, it might be argued that patent pools are true collaborative licensing measures (referring to models where people work together), whereas clearinghouses could be typified as collective licensing measures (referring to models which involve all members, but without presupposing prior collaboration between them). See G. Van Overwalle, 'Individualism, Collectivism and Openness in Patent Law: from Exclusion to Inclusion Through Licensing, in Individualism and Collectiveness in Intellectual Property Law, Jan Rósen (ed.), Cheltenham, Edward Elgar [2012] 71-114.

${ }^{119}$ Cf. E. van Zimmeren et al. [2011] footnote 15, 1, 3.

${ }^{120}$ Furthermore, it is worth noting that other institutional modes of collaboration have cropped up in the life sciences, such as public private partnerships (PPPs). These collaborative initiatives involve active commitment and knowledge spill-overs between companies, customers, suppliers, universities, research institutes, consortia and start-ups. Hence, there is a need for well-tailored IP strategies that support the spirit of the collaboration, enable knowledge flows, allow for value appropriation and facilitate commercialization. See H. Stevens, G. Van Overwalle, B. Van Looy \& I. Huys, ' IP Policies in Early-Phase Research in Public-Private Partnerships: An Overview and Assessment of Current Practices' [2016], Nature Biotechnology (In Press); H. Stevens, G. Van Overwalle, B. Van Looy \& I. Huys, 'Innovative Medicines Initiative (IMI) Case Study Analysis Reveals the True Added Value of Early-Phase PublicPrivate Partnerships (PPPs) [2015], 34 Biotechnology Law Report, 153-165; H. Stevens, G. Van Overwalle, B. Van Looy \& I. Huys, 'Perspectives and Opportunities for Precompetitive Public-Private Partnerships in the Biomedical Sector' [2013], 32 Biotechnology Law Report, 131-139; D. Nicol, J. Nielsen, J Liddicoat, C Critchley and $\mathrm{T}$ Whitton, The Innovation Pool in Biotechnology. The Role of Patents in Facilitating Innovation, Hobart: Centre for Law and Genetics Occasional Paper No. 8 [2014], 285 p. New legal problems are likely to emerge, see E. van Zimmeren et al. [2011] footnote 15, 1, 3

${ }^{121}$ Commission Regulation (EU) No. 316/2014 on the application of Article 101(3) of the Treaty on the Functioning of the European Union to categories of technology transfer agreements, OJ L, 93/17, 28 March 2014.
} 
Technology Transfer Agreements. ${ }^{122}$ Close examination of this regulation and the guidelines provides valuable information on the attitude of European authorities towards patent pools. In short, in the European Union, the creation and organization of patent pools will most probably be accepted if they meet the seven conditions of the "safe harbor' provided by the guidelines. The seven conditions include: open participation to the creation of the pool to all interested parties, inclusion of essential technologies, sufficient safeguards regarding the exchange of sensitive information, non-exclusive licenses to the pool, FRAND-terms, ban on non-challenge clause (including termination clause), authorization to develop competing products and technology. ${ }^{123}$ So, just to point to one issue: if a platform meets the patent pool definition, only essential patents can be collected on the platform.

The European rules do not contain any explicit guidance relating to clearinghouses. However, parties to clearinghouses should also be aware of the potentially anticompetitive restrictions in their agreement that might lead to a violation of competition law. The concerns of the competition authorities might vary according to the actual legal structure chosen for the clearinghouse (for example, a private entity that comprises patent holders as its members, or a neutral, independent, public clearing institution). ${ }^{124}$ In general, we take the view that clearinghouses may contain essential and complementary patents, as well as substitute patents.

The cases under study in fact seem to be mostly clearinghouses, rather than patent pools in the strict legal sense. We therefore assume that the presence of both essential and substitute patents on their platforms will not trigger any anti-competitive problems as a matter of principle. Besides, rather than fixating too one-sidedly on the question of which precise institutional structure shall be implemented (a patent pool or a clearinghouse), priority should be given to the question of which ultimate objective the collaborative mechanism wishes to serve, a market failure or a developmental/societal problem. As to policy driven/pull models, it might be desirable to loosen competition law rules for such non-profit initiatives. ${ }^{125}$

\subsubsection{Liability rule analysis. Level of openness}

A second reason to look into the institutional architecture of collaborative licensing platforms relates to their ability to transform the property rule into a liability rule. Collaborative licensing platforms, such as patent pools and patent clearinghouses, may turn the property rule into a (private) liability rule, crafting guaranteed access to patents, in the sense that licenses have not to be bargained and negotiations cannot result in a veto to access the patented technology. The concept of liability rules finds its origin in the entitlement theory articulated by Calabresi \& Melamed in their epoch-making contribution 'Property Rules, Liability Rules, and Inalienability: One View of the

\footnotetext{
${ }^{122}$ Guidelines on the application of Article 101 of the Treaty on the Functioning of the European Union to technology transfer agreements, OJ C 89/03, 28 March 2014.

123 Paragraph 261 of the Guidelines. Also see M. Konigs, 'The Guidelines on technology transfer agreements: the second edition and its consequences on patent pools' [2014] 9 JIPLP, 1012-1016.

${ }^{124}$ E. van Zimmeren [2009] footnote 15, 63-119.

${ }^{125} \mathrm{G}$. Van Overwalle [2009] footnote 15, $381 \mathrm{ff}$.
} 
Cathedral'. ${ }^{126}$ Entitlement theory mainly distinguishes between entitlements protected by property or liability rules. As Merges puts it, property rules are "absolute permission rules": one cannot take the entitlements without prior permission of the holder, whereas liability rules are "take now, pay later" rules: others can use the entitlement without permission of the owner, so long as they adequately compensate the owner later. ${ }^{127}$ Translating the Calabresi-Melamed concepts to the IP arena, Reichman describes a liability rule as a rule "that takes the form of an automatic license without the power to exclude". ${ }^{128}$

Patent pools, requiring as a matter of competition law open and non-discriminatory licensing policies vis à vis everyone, convert the exclusivity principle of patent protection into a liability regime. A patent pool is an example of a contractually-constructed liability regime, created when "contracting parties start with property rule entitlements, and wind up subject to a collectively-determined liability rule", ${ }^{129}$ which takes place when stakeholders voluntarily seek to obtain private ordering with outcomes that differ from what the default rules of IP law might otherwise provide. ${ }^{130}$ Put differently, patent pools create universal (open to all) and conditional openness, the condition being payment of a fee; in exchange for a fee, they turn exclusive patent rights into commonly shared assets. $^{131}$

Standardized and royalty collecting clearinghouses, if characterized by ex ante disclosure of standardized licensing and royalty conditions, also convert the exclusivity principle of patent protection into a liability regime thereby creating universal and conditional access, the condition being payment of a fee. This type of clearinghouse also turns the exclusive patent right into shared use. ${ }^{132}$ However, if the licenses offered by the clearinghouse are only available for qualified users, the effect would be restricted access, and the transformation from a property rule dominated to a liability rule governed regime would not take place. In this regard, technology exchange clearinghouses do not always trigger the transformation from a right to exclude to a right to remuneration, as they might mainly serve as a marketplace to find licensing partners, where the patent holder keeps

\footnotetext{
${ }^{126}$ G. Calabresi and A.D. Melamed, 'Property Rules, Liability Rules, and Inalienability: One View of the Cathedral' [1972] 85 Harv. L. Rev., 1089-1092. This title refers to Claude Monet's series of paintings of Roeun Cathedral, implying that the authors' academic analysis is but one look at a subject that can be considered from various points of view.

${ }^{127}$ Merges [1996] footnote 27, at 1293, 1302.

128 See J. H. Reichman, 'Of Green Tulips and Legal Kudzu: Repackaging Rights in Subpatentable Innovation' [2000] 53 Vanderbilt Law Review, 1743-1798. Also see J.H. Reichman and T. Lewis, 'Using Liability Rules to Stimulate Innovation in Developing Countries: Application to Traditional Knowledge', in International Public Goods and Transfer of Technology Under a Globalized Intellectual Property Regime, K.E. Maskus and J.H. Reichman (eds.), 2005, 337-366. For an up to date analysis, see Krauspenhaar who qualifies collaborative licensing platforms as 'private liability rules' (Krauspenhaar [2015] footnote 33, at $26 \mathrm{ff}$.

${ }^{129}$ See Merges [1996] footnote 27, at 1303, who called the process of creating "contracting into liability rules", and the resulting organizations "private liability rule organizations".

${ }^{130}$ See J. H. Reichman \& P. Uhlir, 'A Contractually Reconstructed Research Commons for Scientific Data in a Highly Protectionist Intellectual Property Environment' [2003] 66 Law and Contemporary Problems, 315-462 from whom the term "contractually-constructed liability regime" has been drawn. Also see Reichman [2000] footnote 128; Reichman \& Lewis [2005] footnote 128.

${ }^{131}$ G. Van Overwalle [2009] footnote 15, at 381; G. Van Overwalle [2012] footnote 118.

132 See G. Van Overwalle [2012] footnote 118.
} 
the authority to exclude certain licensees, and where - in the event the licensee is accepted - licenses are individually crafted. ${ }^{133}$

From the cases under study, the Syngenta e-Licensing platform manifestly meets the criteria to transform the property rule into a liability rule. This platform provides universal (open to all), and conditional openness (payment of a fee), where the details have been clarified ex ante (fixed fee or customized menus of licensing terms tailored to the needs of different licensee profiles). ${ }^{134}$ Also the IPL Vegetable platform meets the criteria to transform the property rule in to a liability regime. ILP Vegetable provides universal (open to all) and conditional openness (payment of an annual fee; contribution of respective patents to the platform) (see Figure 6). The implementation of a reciprocity rule into the platform does not seem to hamper the universality of the openness, as everyone is invited to join the platform under this condition. On the contrary, the quidpro-quo mechanism may well trigger technology holders, who are hesitant or unwilling to commit their patents to the platform, to participate in the platform and ultimately enlarge the total portfolio of patents available on the platform to include all interested users. More unclear is the MPP, where the licenses offered seem only available for qualified users, namely generic manufacturers. In practice, however, such an effect might be negligible, as apart from the qualified users no one would probably (wish to) apply.

The transition from a property rule to a liability rule has met with considerable sympathy in academic circles, researching initiatives which fuel the sharing ideology. ${ }^{135}$ However, it is important to note that a liability rule regime - shifting the control over the gate of access to technology from patents to fees - may lead to a system where no longer patents but (exorbitant) fees hinder access to technology. The recent literature on patent hold-up illustrates this point very well. Patent hold-up might occur when a patent holder is able and has an incentive to claim royalties that far exceed the economic value of the protected invention. If a user who requires a licence has already invested in a technology and the switching costs are higher than the requested royalties, it would hardly have another choice but to pay excessively high royalty rates demanded by the patent owner. The risk of being held up might become higher when patent ownership is dispersed. Hold-up might deter firms' investments in innovation. ${ }^{136}$

\subsection{Disputed effect on innovation}

From the very onset, the economic impact of collaborative licensing mechanisms has been discussed. An old concern revolves around the question whether patent pools and

\footnotetext{
133 See G. Van Overwalle [2012] footnote 118.

${ }^{134}$ E. van Zimmeren [2009] footnote 15.

135 See S. Dusollier, 'Sharing Access to Intellectual Property through Private Ordering' [2007] ChicagoKent Law Review, 1391, 1416-1427. Also see G. Van Overwalle, 'Inventing Inclusive Patents. From Old to New Open Innovation' [2015] 1 Kritika: Essays on Intellectual Property, P. Drahos, G. Ghidini \& H. Ullrich (eds.), Edward Elgar, 2015, 206-277.

136 See EPO Economic and Scientific Advisory Board (ESAB), Report on Patent aggregation and its impact on competition and innovation policy, Munich, 25 November 2014 (available at http://www.epo.org/about-us/office/esab/workshops.html, last visited October 23, 2015).
} 
clearinghouses create "markets for lemons," 137 and whether they succeed in attracting valuable patents. Over the last years, research is increasingly concentrating on the question to what extent collaborative licensing mechanisms encourage innovation in general, and 'open innovation' in particular.

\subsubsection{Effect on innovation in general}

Patent pools are expected to encourage innovation, as they eliminate stacking licenses, reduce licensing transaction costs through the introduction of a system of 'one stop licensing' for non-member licensees, decrease patent litigation and stimulate funding for research and development. ${ }^{138}$ However, empirical evidence on the effects of patent pools on innovation is scarce. Recent research from Lampe and Moser uses data from the first patent pool in US history - the sewing machine pool (1856-1877) - to investigate the potential effects of a pool on the rate and direction of technical change and innovation. Contrary to theoretical predictions, the sewing machine pool appears to have reduced, rather than increased the rate of technical change in sewing machines, in particular for the members of the pool. ${ }^{139}$ Patenting declined after the creation of the pool, ${ }^{140}$ and alternative measures of innovation confirm that the rate of technical change slowed after the pool had formed and increased again after it had dissolved. Follow on research from Lampe and Moser further indicates that pools may also alter the direction of technical change in an unexpected way. The creation of a patent pool may encourage, rather than discourage innovation in (technologically inferior) substitutes and divert R\&D from pool technologies towards substitutes. ${ }^{141}$

More empirical research would be welcome to further investigate the presumed negative and dis-incentivizing effect of patent pools in the life sciences, and the extent to which the same conclusion holds for clearinghouses. Recent research seems to suggest that the

\footnotetext{
137 G. A. Akerlof, 'The Market for 'Lemons': Quality Uncertainty and the Market Mechanism' [1970], 84 Quarterly J. Econ. 488.

${ }^{138}$ Supra, Section 3.1.1.

${ }^{139}$ Lampe \& Moser found reduction in patenting and innovation (notably in stiches per minute, as an objectively quantifiable measure of performance) from members in the pool (lockstitch technology), in contrast to non-members, exploring inferior technologies (chain technology). The pool fostered innovation in competing technology (chain stitch) by new firms.

${ }^{140}$ R. Lampe and P. Moser, 'Do Patent Pools Encourage Innovation? Evidence from the 19th-Century Sewing Machine Industry' [2010] June 8?

${ }^{141}$ R. Lampe and P. Moser, 'Patent Pools and the Direction of Innovation' [2010] December 19; R. Lampe and P. Moser, 'Patent Pools and the Direction of Innovation. Evidence from the 19th-Century Sewing Machine Industry', National Bureau of Economic Research (NBER) Working Paper Series [2011] November (Working Paper 17573, available at http://www.nber.org/papers/w17573, last visited October 12, 2015). Lampe and Moser found that non-members were exploring substitute, inferior technologies (chain technology) and conclude that the pool fostered innovation in competing technology (chain stich) by new firms. The main difference between chain stitch and lockstitch are the threads: chain stitch uses only one thread (which breaks faster), whereas lockstitch uses two threads (one through the loops of the other, in chainstitch the same thread goes through its own loops). See http://home.howstuffworks.com/sewingmachine1.htm (last visited October 13, 2015).
} 
negative effect applies to both pools and clearinghouses, or any regime that turns the property rule regime into a liability rule. ${ }^{142}$

\subsubsection{Effect on 'open innovation'}

Recent economic literature has paid a lot of attention on 'open innovation' 143 and on the role of IP and collaborative licensing platforms in facilitating open innovation. The term open innovation was coined by Henry Chesbrough in $2003,{ }^{144}$ who defined open innovation as "the use of purposive inflows and outflows of knowledge to accelerate internal innovation and expand markets for external use of innovation, respectively". ${ }^{145}$ Taken together, this strand of economic research provides empirical evidence for firms' increased reliance upon external sources of knowledge to accelerate internal research and development. ${ }^{146}$ In both economic and legal research it was clarified that open innovation heavily relies on $\mathrm{IP}^{147}$ and on licensing agreements as an organizational mode to pursue innovation, both for inbound and outbound open innovation. ${ }^{148}$ Thoughtful scholars have suggested that collaborative license mechanisms are no longer mainly established to deal with (milder forms of) patent fragmentation in the life sciences, but might assist in establishing 'open innovation' in that area. ${ }^{149}$

An empirical study we undertook on the role of collaborative licensing models in the life sciences - more in particular in medical biotechnology, which was undertaken in 20072008 in parallel in Europe ${ }^{150}$ and in Australia ${ }^{151}$ - added meaningful insights to the debate. The findings revealed that respondents generally had more experience with bilateral licencing (one-to-one licencing) and cross-licensing, than with patent pools or clearinghouses. In addition, stakeholders clearly favoured bilateral licences over collaborative licensing models. Patent owners are especially concerned about the loss of control of the bargaining process and licensing conditions, the loss of exclusivity and the

\footnotetext{
142 See Krauspenhaar [2015] footnote 33, additionally pointing to problems of under-compensation, underuse and free-riding under a liability rule regime.

${ }^{143}$ For a recent review of the economic literature, see A. B. Kovács, B. Van Looy and B. Cassiman, 'Exploring the scope of open innovation: a bibliometric review of a decade of research'[2015] 104 Scientometrics, 951-983.

${ }^{144} \mathrm{H}$. Chesbrough, Open Innovation: the New Imperative for Creating and Profiting from Technology, Harvard Business School Press, 2003.

${ }^{145}$ H. Chesbrough, Open Business Models: How to Thrive in the New Innovation Landscape, Harvard Business School Press, 2006.

146 Ibidem.

${ }^{147}$ B. Hall, 'Open Innovation and Intellectual Property Rights - The Two-edged Sword', Japan Spotlight, Jan/Feb issue, 2010, issue, 18-19; G. Van Overwalle, 'Open innovatie en intellectuele eigendom' [Open innovation and intellectual property], Lessen voor de eenentwintigste eeuw. Interdisciplinariteit en wetenschap [Teachings for the twenty first century. Interdisciplinarity and Science], Bart Pattyn en Bart Raymaekers (eds.), Leuven, University Press [2011] 287-308; E. van Zimmeren [2011] footnote 14; E. van Zimmeren et al. [2011] footnote 15.

${ }^{148}$ E. van Zimmeren [2011] PhD Thesis, footnote 14.

${ }^{149}$ See E. van Zimmeren [2011] PhD Thesis, footnote 14. Also see Van Overwalle [2011] footnote 147.

${ }^{150}$ E. van Zimmeren et al. [2011] footnote 39. Also see E. van Zimmeren et al. [2011] footnote 15, 569-576.

${ }^{151}$ D. Nicol, Patent Licensing in Medical Biotechnology in Australia: A Role for Collaborative Licensing Strategies [2010] Centre for Law and Genetics, Occasional Paper No. 7, Hobart, 76 p.
} 
loss of secrecy when they participate in a collaborative licensing scheme. ${ }^{152}$ More recent empirical case study research on collaborative licensing strategies in the medical field supports these earlier findings that collaborative license strategies are conceived to provide little advantage. ${ }^{153}$ So, to date there has not been compelling evidence of industry-wide interest in the adoption of patent pools, clearinghouses or other IP-related collaborative strategies in biotechnology, and formalised collaborative strategies seem to have no great appeal for industry. It remains to be seen to what extent the emergence of aggregation as a means of acquiring a package of tools is seen as a more meaningful alternative. $^{154}$

Furthermore, 'open innovation' is increasingly coming under legal scrutiny, resulting in attention for new complex legal problems, such as co-ownership in all kinds of collaborative agreements. ${ }^{155}$

\section{Conclusions}

Over the last decade, concerns have been expressed that the life sciences are crowded with patents, to the extent that the freedom to use protected inventions may be considerably limited. Recent empirical research indicates that the emergence of a wide patent thicket problem in the life sciences has not actuated as a worldwide phenomenon, and that the expected global impact has been less profound. If there is a patent thicket problem in the life sciences, it may sector-wise well be limited to genetic diagnostics and it may geographically mainly be restricted to the US. Past and present empirical research indicates that there is no strong evidence for the existence of devastating patent thickets, frustrating the use of technology and ultimately leading to a 'tragedy of the anticommons', in the field of genetics. So, time has come to put this alluring metaphor, which intensely dominated the (academic) debate for the last 15 years, to rest in the area of genetics.

Starting from the assumption that the outcrop of patents might result in hindering patent thickets in specific sectors, such as genetic diagnostics, various measures were contemplated over the past decade to facilitate access to fragmented patented technology and render scattered proprietary inventions accessible for further use. Patent pool schemes and clearinghouse models were suggested to settle the presence of multiple patents and multiple patent holders and offer a solution for inventors who wish to gain access to a cluster of patents.

The fact that the hypothesized tragedy of the anti-commons did not manifestly occur, may well provide an explanation why patent pools and clearinghouses have not emerged widely in the life sciences over the last years. Another reason may be the lack of knowledge or the negative perception of these models. Yet, another explanation why pools and clearinghouses have not developed exponentially, may be that the key

\footnotetext{
${ }^{152}$ E. van Zimmeren et al. [2011] footnote 39. Also see E. van Zimmeren et al. [2011] footnote 15.

153 J. Nielsen et al. [2014], footnote 41.

154 J. Nielsen et al. [2014] footnote 41, at 181, 209.

155 See A. Gorbatyuk, G. Van Overwalle \& E. van Zimmeren, 'The Role of IP law and Contract Law in the Allocation of IP Ownership in Coupled Open Innovation Processes', International Review of Intellectual Property and Competition Law (IIC), [2016] (forthcoming).
} 
objective of patent pools and clearinghouses - addressing fragmentation - has been taken up by other actors, such as patent aggregators. In response, existing pools and clearinghouses have developed new tasks and additional services - such as providing legal, financial and negotiation assistance.

On the other hand, the emergence of collaborative license mechanisms with a different objective can be witnessed. Rather than addressing fragmentation, platforms have lately been created to facilitate transfer of single (potentially blocking) patents. Furthermore, the creation of platforms with hybrid structures can be observed, mixing characteristics from both patent pools and clearinghouses. Last but not least, other institutional modes of collaboration have cropped up in the life sciences, such as public private partnerships (PPPs), resulting in new types of legal problems.

Future research may focus on new areas of concern. It has been argued that litigation and ever-evolving technological and business models have killed business strategies based on patented and monopoly-priced genes, exemplified in the Myriad case. ${ }^{156}$ Academic inquiry should investigate new strategies of closing off access to technology or knowledge by way of proprietary databases of genetic test information. ${ }^{157}$

Future research might also investigate the conceptual, legal and practical differences between collaborative licensing platforms discussed here, and 'sharing platforms' epitomized by Airbnb, Uber and Couchsurfing. Current legal debates mainly focus on the treatment of activities taking place within the sharing economy under competition law, tax law, anti-discrimination law, consumer law, liability law, and to the status of tangible property involved. ${ }^{158}$ However, scholarly literature on the sharing economy has devoted little attention so far to the sharing discourse in the field of intangible, intellectual property.

Last but not least, future research may also investigate new models fostering sharing of IP, such as the recently proposed 'inclusive patent' regime. ${ }^{159}$

\footnotetext{
${ }^{156}$ J. Liddicoat et al. [2015] footnote 40, with reference to J. S. Sherkow \& C. Scott, 'Myriad Stands Alone' [2014] 32 Nature Biotechnology, 620. Also see Huys et al. [2012], footnote 1, suggesting that we might be witnessing the Darwinian fate of patents on genes, genetic sequences and methods.

${ }^{157}$ D. Burk, ' Patents as Data Aggregators in Personalized Medicine' [2015] Boston University Journal of Science and Technology Law (Forthcoming), UC Irvine School of Law Research Paper No. 2015-47 (available at http://papers.ssrn.com, last visited October 27, 2015); R. M. Cook-Deegan, J. M. Conley, J.P. Evans, \& D. Vorhaus, 'The next controversy in genetic testing: clinical data as trade secrets? [2013] European Journal of Human Genetics, 585-588.

158 Zale, K., 'Sharing Property', University of Colorado Law Review, forthcoming (2016) and the references cited there (available at www.ssrn.com, last visited February 2, 2016).

${ }^{159}$ See Van Overwalle [2015] footnote 135. Also see S. Dusollier [2007] footnote 135.
} 


\begin{tabular}{|c|c|c|c|c|c|c|c|c|}
\hline & $\begin{array}{l}\text { Medicines } \\
\text { Patent Pool } \\
\text { (MPP) }\end{array}$ & $\begin{array}{l}\text { Golden rice } \\
\text { pool }\end{array}$ & $\begin{array}{l}\text { WIPO } \\
\text { Re:Search }\end{array}$ & PIPRA & ILP Vegetable & Librassay & $\begin{array}{l}\text { Syngenta e- } \\
\text { Licensing }\end{array}$ & Enza Zaden \\
\hline Subject & $\begin{array}{l}\text { Health care } \\
\text { (Medicines against } \\
\text { HIV) }\end{array}$ & $\begin{array}{l}\text { Agriculture } \\
\text { (Rice enriched with } \\
\text { B-carotene) }\end{array}$ & $\begin{array}{l}\text { Health care } \\
\text { (Medicines against } \\
\text { NTDs) }\end{array}$ & Agriculture & $\begin{array}{l}\text { Agriculture } \\
\text { (Vegetable plant } \\
\text { traits) }\end{array}$ & $\begin{array}{l}\text { Health care } \\
\text { (Tests for } \\
\text { personalized } \\
\text { treatment) }\end{array}$ & $\begin{array}{l}\text { Agriculture } \\
\text { (Native plant traits } \\
\text { and enabling } \\
\text { technologies) }\end{array}$ & $\begin{array}{l}\text { Agriculture } \\
\text { (Selection of plant } \\
\text { trait technologies) }\end{array}$ \\
\hline Objective (direct) & $\begin{array}{l}\text { Address } \\
\text { fragmentation } \\
\text { of multiple } \\
\text { patents }\end{array}$ & Fragmentation & Fragmentation & Fragmentation & $\begin{array}{l}\text { Address } \\
\text { blockage of } \\
\text { single patent(s) }\end{array}$ & Fragmentation & Blockage & Blockage \\
\hline Objective (final) & $\begin{array}{l}\text { Pull - } \\
\text { policy driven }\end{array}$ & Pull & Pull & Pull & $\begin{array}{l}\text { Push - } \\
\text { market driven }\end{array}$ & Push & Push & Push \\
\hline Formation & Post-product & Post-product & Pre-product & Pre-product & Pre-product & Pre-product & Pre-product & Post-product \\
\hline Initiative & $\begin{array}{l}\text { Voluntary } \\
\text { Government } \\
\text { (UN) }\end{array}$ & $\begin{array}{l}\text { Voluntary } \\
\text { Government } \\
\text { (University) }\end{array}$ & $\begin{array}{l}\text { Voluntary } \\
\text { Mixed } \\
\text { (WIPO/BVGH) }\end{array}$ & $\begin{array}{l}\text { Voluntary } \\
\text { Government } \\
\text { (University) }\end{array}$ & $\begin{array}{l}\text { Voluntary } \\
\text { Industry }\end{array}$ & $\begin{array}{l}\text { Voluntary } \\
\text { Industry }\end{array}$ & $\begin{array}{l}\text { Voluntary } \\
\text { Industry }\end{array}$ & $\begin{array}{l}\text { Voluntary } \\
\text { Industry }\end{array}$ \\
\hline Participants & Mixed & Mixed & Mixed & Mainly public & Mainly private & Mainly private & Private & Private \\
\hline $\begin{array}{l}\text { Relationship between } \\
\text { participants }\end{array}$ & $\begin{array}{l}\text { No multiparty } \\
\text { set-up } \\
\text { agreement }\end{array}$ & $\begin{array}{l}\text { No multiparty } \\
\text { set-up } \\
\text { agreement }\end{array}$ & $\begin{array}{l}\text { No multiparty } \\
\text { set-up } \\
\text { agreement }\end{array}$ & $\begin{array}{l}\text { No multiparty } \\
\text { set-up } \\
\text { agreement }\end{array}$ & $\begin{array}{l}\text { Multiparty set- } \\
\text { up agreement }\end{array}$ & $\begin{array}{l}\text { No multiparty } \\
\text { set-up } \\
\text { agreement }\end{array}$ & NA & NA \\
\hline Management & $\begin{array}{l}\text { Independent } \\
\text { administrator }\end{array}$ & $\begin{array}{l}\text { Independent } \\
\text { administrator }\end{array}$ & $\begin{array}{l}\text { Independent } \\
\text { administrator }\end{array}$ & $\begin{array}{l}\text { Independent } \\
\text { administrator }\end{array}$ & $\begin{array}{l}\text { Independent } \\
\text { administrator }\end{array}$ & $\begin{array}{l}\text { Independent } \\
\text { administrator }\end{array}$ & Patent holder & Patent holder \\
\hline Patents & $\begin{array}{l}\text { Essential + } \\
\text { substitute }\end{array}$ & $\begin{array}{l}\text { Mostly } \\
\text { essential }\end{array}$ & $\begin{array}{l}\text { Essential + } \\
\text { substitute }\end{array}$ & $\begin{array}{l}\text { Essential + } \\
\text { substitute }\end{array}$ & $\begin{array}{l}\text { Essential + } \\
\text { substitute }\end{array}$ & $\begin{array}{l}\text { Essential + } \\
\text { substitute }\end{array}$ & $\begin{array}{l}\text { Essential + } \\
\text { substitute }\end{array}$ & $\begin{array}{l}\text { Essential + } \\
\text { substitute }\end{array}$ \\
\hline Licensing terms & Standardized & & Negotiable & Negotiable & Negotiable & Standardized & Standardized & Standardized? \\
\hline Openness & Universal? & Universal & Universal & Universal & Universal & Universal & Universal & Universal \\
\hline Legal qualification & Hybrid & Hybrid & $\begin{array}{l}\text { Technology } \\
\text { exchange } \\
\text { clearinghouse }\end{array}$ & $\begin{array}{l}\text { Technology } \\
\text { exchange } \\
\text { clearinghouse }\end{array}$ & Hybrid? & $\begin{array}{l}\text { Standardized } \\
\text { clearinghouse }\end{array}$ & $\begin{array}{l}\text { Standardized } \\
\text { clearinghouse }\end{array}$ & $\begin{array}{l}\text { Standardized } \\
\text { clearinghouse? }\end{array}$ \\
\hline
\end{tabular}

Table 2. Characteristics of patent pools and clearinghouses in the life sciences 